\title{
Review
}

\section{Dissecting autoimmune diabetes through genetic manipulation of non-obese diabetic mice}

\author{
Y. Yang ${ }^{1}$, P. Santamaria ${ }^{1,2}$ \\ 1 Julia McFarlane Diabetes Research Centre, The University of Calgary, Faculty of Medicine, Calgary, Alberta, Canada \\ 2 Department of Microbiology and Infectious Diseases, Julia McFarlane Diabetes Research Centre, The University of Calgary, \\ Faculty of Medicine, Calgary, Alberta, Canada
}

\begin{abstract}
Type 1 diabetes results from a genetically and immunologically complex autoimmune process that is specifically directed against the pancreatic beta cells. Non-obese diabetic mice spontaneously develop a form of autoimmune diabetes closely resembling the disease in humans. This happens because, like human diabetic patients, non-obese diabetic mice have an unfortunate combination of apparently normal alleles at numerous loci associated with Type 1 diabetes. In isolation, each of these allelic variants affords a small degree of susceptibility to diabetes. In combination, however, they set in motion a series of immunological events that lead to islet inflammation and overt diabetes. Type 1 diabetes is associated with defects in selftolerance and immunoregulation. It involves presentation of beta cell antigens to autoreactive $\mathrm{T}$ lympho-
\end{abstract}

cytes by professional antigen-presenting cells, the recruitment of antigen-activated $\mathrm{T}$ cells into pancreatic islets, and the differentiation of these antigen-activated lymphocytes into beta cell killers. Understanding the precise sequence of events in the pathogenesis of Type 1 diabetes has been, and remains, a challenging task. Much of our understanding of the immunology of the disease stems from studies of genetically engineered, non-obese diabetic mice. These mice provide reductionist systems, with which the contribution of individual cellular elements, molecules or genes to the disease process can be dissected. This review focuses on the lessons that have been learned through studies of these mice. [Diabetologia (2003) 46:1447-1464]

Keywords Non-obese diabetic mice, autoimmune, immunology, lymphocytes, pathogenesis, Type 1 diabetes.
Received: 12 May 2003 / Revised: 10 July 2003

Published online: 28 October 2003

C) Springer-Verlag 2003

Corresponding author: Dr. P. Santamaria, Department of Microbiology and Infectious Diseases, Julia McFarlane Diabetes Research Centre, The University of Calgary, Faculty of Medicine, 3330 Hospital Drive N.W., Calgary, Alberta, Canada T2 N 4N1

E-mail: psantama@ucalgary.ca

Abbreviations: APCs, antigen-presenting cells; $\beta 2 \mathrm{~m}$, beta- 2 microglobulin; CD62L, L-selectin; CDR3, complementaritydetermining region 3; CTL, cytotoxic T lymphocyte; DC, dendritic cell; IA-2, insulinoma-associated protein 2; ICA69, islet cell antigen $69 \mathrm{KDa}$; ICAM-1, intercellular adhesion molecule-1; IFN- $\gamma$, interferon- $\gamma$; LFA-1, leucocyte function-associated antigen-1; mAb, monoclonal antibody; NK, natural killer; MIP- $1 \alpha$, macrophage inflammatory protein $1 \alpha$; NOD, nonobese diabetic; 8.3-NOD, 8.3-TCR $\alpha \beta$-transgenic NOD mice; PLN, pancreatic lymph node; rag, recombination-activating gene; RAG-2, recombination-activating gene 2; RIP, rat insulin promoter; TCR, T cell receptor.

\section{Introduction}

In humans and non-obese diabetic (NOD) mice Type 1 diabetes results from a chronic autoimmune process against the pancreatic beta cells. There is extensive evidence that for Type 1 diabetes to develop autoreactive $\mathrm{CD}^{+}$and $\mathrm{CD}^{+} \mathrm{T}$ lymphocytes have to be activated in the pancreatic lymph nodes (PLNs) and recruited into pancreatic islets. These antigen-activated $\mathrm{T}$ lymphocytes progressively destroy the pancreatic beta cells, bringing about clinical disease after a long period of islet inflammation. Macrophages, dendritic cells (DCs) and B lymphocytes are also key factors in the disease process, notably as antigen-presenting cells (APCs). These different types of immune cells contribute to the development of Type 1 diabetes by participating in complex multi-cellular interactions, which are directed by cytokines and chemokines, and modulated by co-stimulatory factors and adhesion 
Table 1. TCR- and BCR-transgenic NOD mice

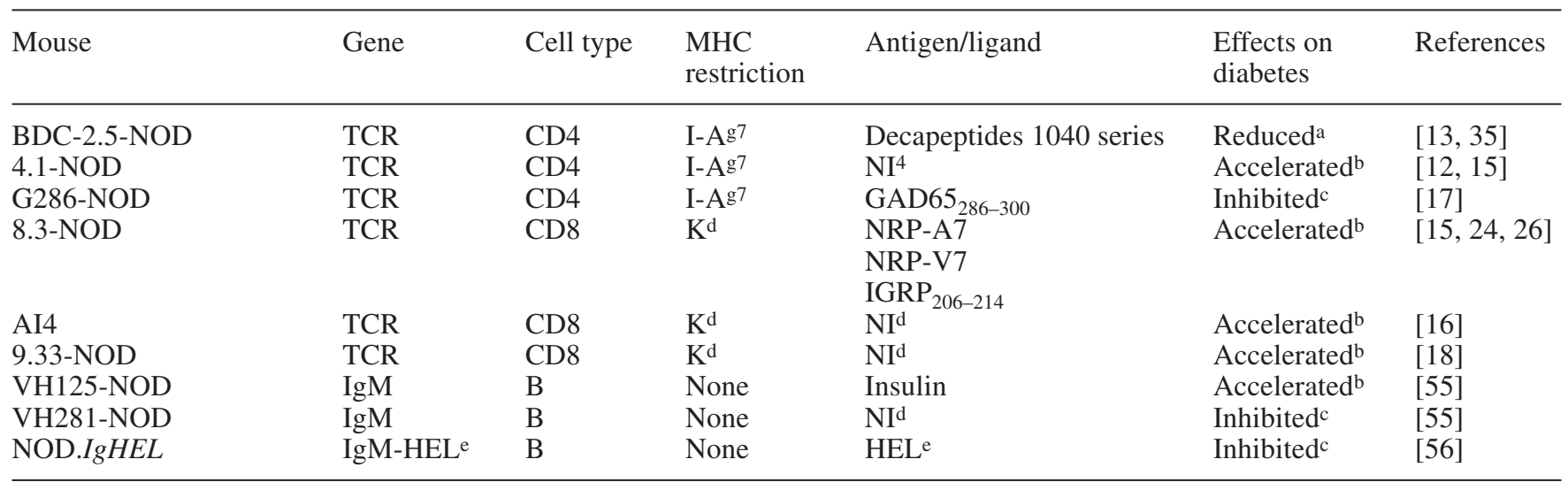

a Lower incidence of diabetes than wild-type NOD mice

d NI, not identified

$\mathrm{b}$ Earlier onset of diabetes than in wild-type NOD mice

e HEL, hen egg lysozyme

c Lower insulitis scores (or absence of insulitis) and no diabetes

Table 2. Transgenic NOD mice

\begin{tabular}{|c|c|c|c|c|}
\hline Mouse & Gene(s) & Promoter & Effects on Type 1 Diabetes & References \\
\hline NOD.RIP-B7.1 & $\mathrm{Cd} 80$ & Insulin & Accelerated ${ }^{c}$ & {$[1]$} \\
\hline NOD.CTLA4-Ig & Ctla4-Ig & Keratin & Increased $^{\mathrm{b}}$ & {$[62]$} \\
\hline NOD.RIP-IL-4 & Il4 & Insulin & Inhibitede & {$[88]$} \\
\hline BDC2.5-NOD.RIP-IL-4 & $I l 4 / B D C 2.5-T C R$ & Insulin & Accelerated $^{c}$ & [89] \\
\hline NOD.RIP-IL-6 & Il6 & Insulin & Delayed & [96] \\
\hline NOD.Glu-TGF $\beta$ & $T g f b l$ & Glucagon & Inhibitede & {$[103]$} \\
\hline NOD.RIP-TNF $\alpha$ & Tnfa & Insulin & Accelerated ${ }^{c}$ & [44] \\
\hline NOD.RIP-IFN- $\gamma \Delta R$ & $\operatorname{Infg} \Delta R$ & Insulin & None & [118] \\
\hline NOD.RIP-FasL & FasL & Insulin & Accelerated $^{c}$ & {$[145]$} \\
\hline NOD.GAD65-Tg & GAD65 & MHC class I & Acceleratedc & [32] \\
\hline NOD. $A S-G A D$ & Antisense-GAD65 & Insulin & Inhibited $^{\mathrm{e}}$ & [29] \\
\hline
\end{tabular}

${ }^{\text {a }}$ Lower incidence of diabetes than in wild-type NOD mice

b Higher incidence of diabetes than in wild-type NOD mice

c Earlier onset of diabetes than in wild-type NOD mice

molecules. Defects in self-tolerance and immunoregulation, brought forth by a combination of ill-defined environmental influences (in humans) and genetic elements (in humans and mice), set these complex cellular interactions in motion. The genetic and immunological complexity of Type 1 diabetes has necessitated the generation of genetically engineered models of Type 1 diabetes. This review summarises the contributions of studies in transgenic, gene-targeted and congenic NOD mice to our understanding of how diabetes develops. The effects of various transgenes, targeted mutations and gene polymorphisms on the natural history of diabetes in NOD mice are summarised in Tables 1, 2, 3, $4[1,2,3,4,5]$.

To the best of our knowledge, the reviewed studies followed the "Principles of laboratory animal care"
${ }^{d}$ Later onset of diabetes than in wild-type NOD mice

e Lower insulitis scores (or absence of insulitis) and no diabetes

(NIH, publication no.85-23, 1985; http://www.grants1. nih.cgov/grants/onlaw/references/phspol.html), complied with specific national laws on animal care, were approved by the relevant ethics committees, and were carried out in accordance with the Declaration of Helsinki (http://www.wma.net/e/policy/17cnote.pdf).

\section{Role of $\mathbf{T}$ cells in Type 1 diabetes}

Early $\mathrm{T}$ cell transfer studies revealed that $\mathrm{CD}^{+}$and $\mathrm{CD}^{+} \mathrm{T}$ cells are necessary for Type 1 diabetes to develop in NOD mice [6]. However, the relative role of each $\mathrm{T}$ cell subset in the disease process remains unclear. Since beta cells do not express MHC class II molecules, it is generally believed that autoreactive 
Table 3. Congenic gene-targeted NOD mice

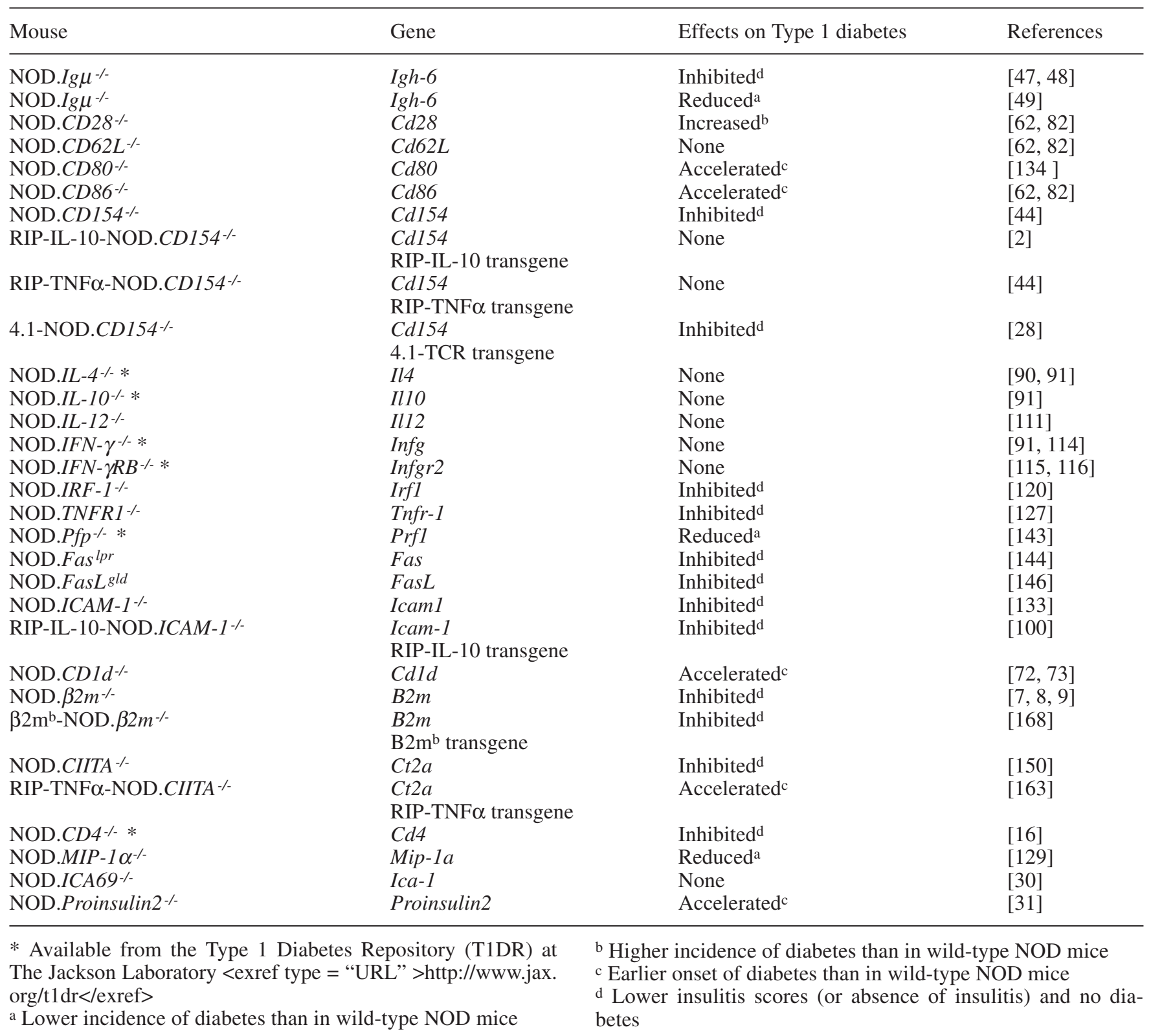

$\mathrm{CD} 4+\mathrm{T}$ cells need to engage beta cell antigens on local APCs to undergo activation. Studies of NOD mice deficient in $\mathrm{CD}^{+} \mathrm{T}$ cells have suggested that the initial insult shedding these beta cell autoantigens into the milieu is mediated by $\mathrm{CD}^{+}$cytotoxic $\mathrm{T}$ lymphocytes (CTLs) [7, 8, 9], which invariably infiltrate the islets of NOD mice (reviewed in [10]). In contrast to this, another view holds that Type 1 diabetes is initiated by CD4 ${ }^{+} \mathrm{T}$ cells (or other cell types). Thus splenic $\mathrm{CD}^{+}{ }^{+} \mathrm{T}$ cells from NOD mice can transfer islet inflammation (insulitis) into immunocompromised hosts, but splenic CD8 ${ }^{+} \mathrm{T}$ cells cannot do this [6]. Moreover, beta cells do not express key co-stimulatory molecules, suggesting that naive autoreactive $\mathrm{CD}^{+}{ }^{+}$ $\mathrm{T}$ cells also need to engage their target antigens on professional APCs to be able to differentiate into CTLs. Finally, genetic susceptibility and resistance to Type 1 diabetes are profoundly affected by polymorphisms of MHC class II genes (reviewed in [11]), which specifically control the development and function of $\mathrm{CD}^{+}{ }^{+} \mathrm{T}$ cells.

The low peripheral precursor frequency and repertoire heterogeneity of pathogenic autoreactive $\mathrm{T}$ cells in NOD mice precludes detailed studies of their developmental biology. During the last decade a number of transgenic NOD mice expressing $\mathrm{T}$ cell receptors (TCRs) that target naturally occurring, non-transgenic beta cell autoantigens have become available $[12,13$, $14,15,16,17,18]$. The rearranged TCR-V(D)J genes expressed by these mice were isolated from islet-spe- 
Table 4. Non-MHCidd loci and NOD mice congenic for non-MHC idd loci

\begin{tabular}{|c|c|c|c|c|c|}
\hline Idd locus & Chromosome & Origin & Effects on Type 1 diabetes & Animal model & References \\
\hline $\operatorname{Idd} 2$ & 9 & $\mathrm{NON}$ & None & Not available & {$[3]$} \\
\hline Idd2 & 9 & B10 & Reduced $^{\mathrm{a}}$ & Not available & [170] \\
\hline $\operatorname{Idd} 3^{*}$ & 3 & B6 & Reduced $^{\mathrm{a}}$ & NOD.B6Idd3 & {$[176]$} \\
\hline Idd4 & 11 & B6 & Reduceda & NOD.B6Idd4 & {$[4]$} \\
\hline $\operatorname{Idd} 5^{*}$ & 1 & B10 & Reduced $^{\mathrm{a}}$ & NOD.B10Idd5 & {$[179,180]$} \\
\hline Idd6 & 6 & PWK & Accelerated ${ }^{c}$ & Not available & {$[170]$} \\
\hline Idd6 & 6 & $\mathrm{C} 3 \mathrm{H}$ & Reduced $^{\mathrm{a}}$ & NOD.C3HIdd6 & [178] \\
\hline Idd6 & 6 & B10 & Reduced $^{\mathrm{a}}$ & Not available & {$[170]$} \\
\hline Idd 7 & 7 & B10 & Increased ${ }^{b}$ & Not available & {$[170]$} \\
\hline Idd 8 & 14 & B10 & Increased $^{b}$ & Not available & {$[170]$} \\
\hline $\operatorname{Idd} 9 *$ & 4 & B10 & Reduced $^{\mathrm{a}}$ & NOD.B10Idd9 & [181] \\
\hline $\operatorname{Idd} 10^{*}$ & 3 & B6 & Reduced $^{\mathrm{a}}$ & NOD.B6Idd10 & {$[182]$} \\
\hline Idd11\# & 4 & B6 & Reduceda & NOD.B6Idd11 & {$[5]$} \\
\hline $\operatorname{Idd} 12$ & 14 & B6 & Reduced $^{\mathrm{a}}$ & Not available & {$[170]$} \\
\hline Idd13 & 2 & NOR & Reduced ${ }^{a}$ & NOD.NORIdd13 & [167] \\
\hline Idd14 & 13 & NON & Reduced $^{\mathrm{a}}$ & Not available & [171] \\
\hline Idd14 & 13 & B6 & Accelerated $^{c}$ & NOD.B6Idd14 & [177] \\
\hline Idd 15 & 5 & NON & Reduced $^{\mathrm{a}}$ & Not available & {$[171]$} \\
\hline Idd16 & 17 & CTS & Reduced $^{\mathrm{a}}$ & NOD.CTSIdd16 & {$[172]$} \\
\hline Idd16 & 17 & $\mathrm{~B} 10 \mathrm{~A}$ & Inhibited ${ }^{d}$ & NOD.B10AG3 & {$[173]$} \\
\hline $\operatorname{Idd} 17^{*}$ & 3 & B6 & Reduced $^{\mathrm{a}}$ & NOD.B6Idd17 & [182] \\
\hline $\operatorname{Idd} 18^{*}$ & 3 & B6 & Reduced ${ }^{a}$ & NOD.B6Idd18 & {$[182]$} \\
\hline$I d d 19$ & 6 & $\mathrm{C} 3 \mathrm{H}$ & Reduced $^{\mathrm{a}}$ & NOD.C3HIdd6Idd19 & {$[178]$} \\
\hline $\operatorname{Idd} 20$ & 6 & $\mathrm{C} 3 \mathrm{H}$ & Reduced $^{\mathrm{a}}$ & NOD.C3HIdd 20 & {$[178]$} \\
\hline
\end{tabular}

Table does not include sub-congenic lines.

* Available from the Type 1 Diabetes Repository (T1DR) at The Jackson Laboratory http://www.jax.org/t1dr or from Taconic Research Farms http://www.taconic.com/emerging/nodmodels/nodcongenics.htm
\# Overlaps with idd 9

a Lower incidence of diabetes than in wild-type NOD mice

$\mathrm{b}$ Higher incidence of diabetes than in wild-type NOD mice

c Earlier onset of diabetes than in wild-type NOD mice

${ }^{\mathrm{d}}$ Lower insulitis scores (or absence of insulitis) and no diabetes cific $\mathrm{T}$ cell clones, which had been propagated from NOD mice, cloned into TCR-expression shuttle vectors and introduced into the mouse germ line. As most of the lymphocytes that develop in these animals express a single TCR, it is possible to do detailed investigations of the mechanisms which control the development, regulation, activation, recruitment and effector function of diabetogenic $\mathrm{T}$ cells in genetic backgrounds prone to and resistant to Type 1 diabetes.

\section{Autoreactive CD8+ $\mathbf{T}$ cells}

The antigenic specificity or specificities of the CD8+ $\mathrm{T}$ cells assumed to be involved in the initiation of Type 1 diabetes are unknown. Several lines of evidence had previously suggested that the antigenic repertoire of these $\mathrm{T}$ cells is restricted. For example, many of the $\mathrm{CD}^{+} \mathrm{T}$ cells isolated from islets of acutely diabetic NOD mice are cytotoxic to beta cells in the context of the MHC class I molecule $\mathrm{H}-2 \mathrm{~K}^{\mathrm{d}}$ and use TCR $\alpha$ chains with homologous complementarity-determining region 3 (CDR3) sequences [19]. Moreover, most $\mathrm{CD}^{+} \mathrm{T}$ cells isolated from islets of transgenic NOD mice expressing the TCR $\beta$ chain of the CD $8^{+}$ clone NY8.3 (which uses a representative CDR3 $\alpha$ se- quence) express endogenous $\operatorname{TCR} \alpha$ chains which are identical to the chain used by the clonotype which donated the TCR $\beta$ transgene [15]. A considerable percentage of $\mathrm{CD}^{+} \mathrm{T}$ cells propagated from the earliest insulitic lesions of NOD mice use this particular TCR $\alpha$ chain, which employs V $\alpha 17$ and J $\alpha 42$ elements [20]. Studies of 8.3-TCR $\alpha \beta$-transgenic NOD mice (8.3-NOD) have shown that $\mathrm{CD} 8{ }^{+} \mathrm{T}$ cells expressing this particular TCR $\alpha$ chain (along with an appropriate TCR $\beta$ chain) are highly diabetogenic [15].

The availability of 8.3-NOD mice afforded a unique opportunity to search for antigenic ligands of CD8+ CTLs relevant to Type 1 diabetes. It is important to note that differentiated CTLs derived from islets of pre-diabetic and acutely diabetic NOD mice are functionally and phenotypically unstable: they either do not survive repeated antigenic stimulation in vitro, or they lose cytotoxic activity within days or weeks in culture [19]. Repeated antigenic stimulation with antigen-pulsed DCs of 8.3-CTLs differentiated in vivo induces transient re-expression of the recombination-activating genes $(\mathrm{rag})$ and TCR revision, leading to loss of beta cell reactivity [21]. The screening of $\mathrm{H}-2 \mathrm{~K}^{\mathrm{d}}-$ binding combinatorial peptide libraries with shortterm-expanded 8.3-CTL lines led to the identification of two major peptide ligands for $\mathrm{T}$ cells expressing the 
prevalent V $\alpha 17-J \alpha 42$ TCR $\alpha$ chain: NRP and NRPA7, an alanine mutant analogue of NRP with superior agonistic properties [22]. Subsequent studies confirmed that these two peptides were recognised by a large proportion of islet-associated $\mathrm{CD} 8^{+} \mathrm{T}$ cells from wild-type NOD mice $[22,23]$. Hyper-mutation of the NRP sequence subsequently led to identification of NRP-V7, a higher affinity ligand of the 8.3-TCR than NRP or NRP-A7 [24]. Using fluorescently labelled peptide/MHC tetramers carrying the NRP-V7 peptide, we later discovered that progression of insulitis to overt diabetes in NOD mice is associated with expansion of the circulating pool of NRP-V7-reactive T cells in peripheral blood [25]. More recently the identity of the naturally occurring ligand of the NRPA7/V7-reactive CD8 ${ }^{+} \mathrm{T}$ cell subpopulation has been discovered using 8.3-CTLs as probes. This ligand is a beta-cell specific protein of unknown function, which resides in the endoplasmic reticulum [26]. The question of whether islet-associated $\mathrm{CD}^{+} \mathrm{T}$ cells in NOD mice target only one or several epitopes from this autoantigen and whether this autoantigen is also targeted by human MHC class I-restricted $\mathrm{CD}^{+} \mathrm{T}$ cells is one of the fundamental issues currently under investigation.

The fact that the NRP-A7/V7-reactive $\mathrm{CD}^{+} \mathrm{T}$ cell subpopulation is prevalent in $\mathrm{T}$ cell infiltrates of islets from NOD mice does not imply that the $\mathrm{CD} 8^{+} \mathrm{T}$ cell response in Type 1 diabetes is exclusively directed against a single autoantigen, let alone a single peptide. One study, for example, has reported that insulitic $\mathrm{CD}^{+} \mathrm{T}$ cells in young NOD mice recognise an insulin-derived peptide [27]. Although we find that these cells represent only a very small fraction of all isletassociated $\mathrm{CD}^{+} \mathrm{T}$ cells, even in young animals $[23$, 25 ], they could still play an important role in the disease process. However, there is also evidence, in islets of NOD mice, for the existence of autoreactive CD8+ $\mathrm{T}$ cells which recognise neither insulin nor the antigenic target of $8.3-\mathrm{CD} 8^{+} \mathrm{T}$ cells $[23,25]$. Explaining the repertoire of $\mathrm{MHC}$ class I-restricted $\mathrm{CD}^{+} \mathrm{T}$ cell responses in murine Type 1 diabetes has obvious diagnostic and therapeutic implications for human Type 1 diabetes.

\section{CD4+ T-cell-assisted recruitment of CD8+ $T$ cells}

Comparative studies of 8.3-NOD mice which were competent or deficient in recombination-activating gene 2 (rag-2) have shown that efficient accumulation of 8.3-CD8 ${ }^{+} \mathrm{T}$ cells into islets requires the assistance of $\mathrm{CD}^{+} \mathrm{T}$ cells $[15,28]$. This, however, is not a universal phenomenon. Thus AI4 CD8 $+\mathrm{T}$ cells are as diabetogenic in the absence of $\mathrm{CD}^{+}{ }^{+} \mathrm{T}$ cells as they are in their presence. The reasons for these differences among strains are unknown, but one possibility is that the need for help from $\mathrm{CD}^{+}{ }^{+} \mathrm{T}$ cells in MHC class I- restricted TCR-transgenic animals is a function of the affinity of the TCRs of $\mathrm{CD}^{+} \mathrm{T}$ cells for peptide/MHC. Whatever the mechanism, it is likely that the peripheral frequency of T-helper-independent, high-avidity, autoreactive $\mathrm{CD} 8^{+} \mathrm{T}$ cells in non-TCRtransgenic mice is too low for these cells to be able to initiate disease without $\mathrm{CD}^{+} \mathrm{T}$ cells (see below). This would explain why disease initiation in wild-type NOD mice requires the coordinated recruitment of $\mathrm{CD} 4^{+}$and $\mathrm{CD}^{+} \mathrm{T}$ cells.

\section{Autoreactive CD4+ T cells}

The antigenic specificity or specificities of autoreactive $\mathrm{CD}^{+} \mathrm{T}$ cells contributing to the initiation of and/or progression to Type 1 diabetes in the NOD mouse are unknown, but several candidates have been considered. Autoreactive $\mathrm{CD}^{+}{ }^{+} \mathrm{T}$ cells from NOD mice recognise a number of islet autoantigens, including insulin, GAD65 and GAD67, the tyrosine phosphatase-like IA-2, phogrin, ICA69, and heat shock protein 60 . NOD mice overexpressing or lacking some of these autoantigens, including GAD65, ICA69 and proinsulin, have been generated [29, 30, 31, 32, 33]. Systemic overexpression of a GAD65 transgene has been found to promote diabetogenesis [32], suggesting that there is a breakdown of tolerance to this autoantigen in NOD mice. In contrast, overexpression of ICA69 or proinsulin 2 transgenes gives variable degrees of diabetes resistance $[33,34]$, possibly by inducing central tolerance of autoreactive lymphocytes. It should be noted that the results of these studies are difficult to reconcile with those obtained in NOD mice lacking these autoantigens (see below).

Islet-specific suppression of GAD65 or GAD67 expression by a rat insulin promoter (RIP)-driven, antisense $G A D$ transgene inhibited the development of insulitis and Type 1 diabetes [29]. Although this result was taken to imply that this autoantigen plays a critical role in the pathogenesis of Type 1 diabetes, the authors didn't formally exclude the potentially confounding contribution of genetic contamination of the transgenic mice to the study's outcome [29]. Disruption of the ICA69 gene in NOD mice did not noticeably change the natural history of Type 1 diabetes, indicating that this autoantigen is dispensable [30]. Interestingly, disruption of the proinsulin 2 gene in NOD mice accelerated diabetes, suggesting that proinsulin-2-reactive $\mathrm{T}$ cells play a regulatory role in this strain [31]. Studies of transgenic NOD mice expressing a GAD65-reactive TCR [17] have also suggested a regulatory role for GAD65-reactive $\mathrm{CD}^{+} \mathrm{T}$ cells in NOD mice. Two other MHC class II (I-A ${ }^{\mathrm{g} 7}$ )-restricted TCRs derived from NOD mice have been studied so far (BDC2.5 and 4.1). Although their natural antigenic ligands remain unknown $[12,13]$, there is evidence that they recognise novel autoantigens. Thus the 
BDC2.5 TCR recognises a mimotope which is homologous to the 528-539 fragment of GAD65 and was defined using combinatorial peptide libraries, but it does not recognise the natural epitope [35]. According to our unpublished observations, 4.1-CD4+ $\mathrm{T}$ cells recognise a beta cell autoantigen other than proinsulin, phogrin, ICA69, IA-2, GAD65 or GAD67.

\section{T cell priming}

It has been recently shown that the PLNs are essential to the development of Type 1 diabetes [36]. Earlier experiments had suggested that diabetogenic $\mathrm{T}$ cells first encounter cognate peptide/MHC complexes in the PLNs [28, 37, 38]. These experiments, which used $\mathrm{T}$ cells labelled with carboxyfluorescein diacetate succinidimyl ester and expressing MHC class I $\left(\mathrm{K}^{\mathrm{d}}\right)$ - or class II-restricted $\left(\mathrm{I}-\mathrm{A}^{\mathrm{g} 7}\right)$, beta-cell-autoreactive TCRs (8.3-CD8 ${ }^{+}$and BDC2.5- or 4.1-CD4 ${ }^{+}$), also showed that priming of these $\mathrm{T}$ cells does not occur in neonatal mice. This suggests that access of beta cell autoantigens to the cross-presentation pathway is developmentally regulated $[37,38]$. In $8.3-\mathrm{CD}^{+} \mathrm{T}$ cells, for example, priming in the PLNs is undetectable up to three weeks after birth. The amount of priming increases with the age of the animal and the extent of beta cell apoptosis in islets, implicating in situ beta cell death in the facilitation of this process. Interestingly, priming of 8.3-CD8 ${ }^{+}, 4.1-\mathrm{CD}^{+}$and $\mathrm{BDC} 2.5-$ $\mathrm{CD}^{+} \mathrm{T}$ cells in NOD mice is preceded by a physiological "wave" of beta cell apoptosis, which peaks at about 2 weeks of age and is independent of $\mathrm{T}$ cells [39]. These observations have led to suggestions that developmental remodelling of beta-cell mass in the post-neonatal period promotes access of beta-cell autoantigens to the cross-presentation pathway. In fact, the earliest $\mathrm{T}$ cell cross-priming event detectable in the PLNs of NOD mice is not affected by expression of a transgene protecting beta cells from cytotoxicity induced by $\mathrm{CD}^{+}$CTLs (Yamanouchi et al., submitted).

\section{T-T collaboration}

Productive collaboration between $\mathrm{CD}^{+}{ }^{+}$T-helper cells and pre-cytotoxic $\mathrm{CD} 8^{+} \mathrm{T}$ cells requires the presentation of different epitopes by the same APC, usually a DC, in a CD40/CD154-dependent manner [40, 41, 42]. CD40 ligation on DCs induces the up-regulation of $\mathrm{T}$ cell co-stimulatory molecules, elicits the production of pro-inflammatory cytokines and endows DCs with the ability to differentiate $\mathrm{CD} 8^{+} \mathrm{T}$ cells. Blockade of the CD40-CD154 pathway inhibits the development of insulitis and diabetes in NOD mice [43, 44]. Whereas disruption of CD154 also protects monoclonal 4.1-TCR-transgenic NOD mice from diabetes, it has no effect on the T-helper-independent diabetogenic activity of 8.3-CD8 ${ }^{+} \mathrm{T}$ cells [28]. In fact, 8.3-CD8 ${ }^{+}$ $\mathrm{T}$ cells do not need CD154 to undergo antigen-driven activation in vivo [28]. Despite this, the ability of Thelper cells to enhance the diabetogenic activity of 8.3-CD8 ${ }^{+} \mathrm{T}$ cells is CD154-dependent, because only $\mathrm{CD} 154^{+} \mathrm{CD} 4^{+} \mathrm{T}$ cells can have this enhancing effect [28]. Systemic activation of DCs with an agonistic anti-CD40 monoclonal antibody (mAb) or with $\mathrm{CpG}$ DNA (a ligand of toll-like receptor 9) was found to bypass the need for $\mathrm{CD} 154^{+} \mathrm{CD} 4{ }^{+} \mathrm{T}$ cells in this system, suggesting that $\mathrm{T}$-helper cells promote the recruitment and activation of autoreactive $\mathrm{CD}^{+} \mathrm{T}$ cells by activating DCs. When expressed locally, TNF $\alpha$ can also overcome the need for CD154 in a non-TCRtransgenic model of diabetes induced by $\mathrm{CD} 8^{+} \mathrm{T}$ cells [44]. However, CD154 does not simply act by ligating CD40 on DCs; ligation of CD154 co-stimulates CD4+ $\mathrm{T}$ cell responses in vitro [45] and in vivo [28].

\section{B lymphocytes}

The activation of CD8 ${ }^{+} \mathrm{T}$ cells in Type 1 diabetes is probably driven by DCs, which have the unique ability to process exogenous antigens via the endogenous pathway of antigen presentation (called "cross-presentation"). Activation, on the other hand, of autoreactive $\mathrm{CD}^{+} \mathrm{T}$ cells appears to involve the recruitment of $\mathrm{B}$ cells as APCs, at least in non-TCR-transgenic NOD mice. People with Type 1 diabetes bear autoreactive $\mathrm{B}$ cells that differentiate into plasma cells capable of secreting non-cytopathic autoantibodies against multiple islet cell antigens. These autoreactive B cells are thought to contribute to Type 1 diabetes development by capturing beta cell antigens via surface immunoglobulins (the B cell receptor) and by presenting epitopes derived from these antigens to autoreactive $\mathrm{CD}^{+}{ }^{+} \mathrm{T}$ cells via MHC class II molecules on the cell surface. Several lines of evidence support the hypothesis that B cells play an important role in Type 1 diabetes: (i) maternal autoantibodies influence diabetes development in the offspring [46]; (ii) Ig $\mu$-gene-deficient NOD mice and NOD mice bearing B cells deficient in MHC class II molecules do not usually develop diabetes [47, 48, 49, 50, 51, 52, 53]; (iii) certain autoreactive $\mathrm{CD}^{+}{ }^{+} \mathrm{T}$ cells do not proliferate in the PLNs of B-cell-deficient NOD mice [54]; and (iv) a reduced peripheral frequency of islet-specific $B$ cells inhibits diabetogenesis, whereas an increased frequency accelerates it $[55,56]$. The suggested ability of B cells to act as APCs in Type 1 diabetes could be agedependent, because the adoptive transfer of B cells into adult B-cell-deficient NOD mice does not restore Tcell mediated autoimmunity [51]. In contrast, other findings suggest that the diabetogenic activity of $\mathrm{B}$ cells in NOD mice is not always necessary, as: (i) splenic $\mathrm{T}$ cells from 5-week-old NOD mice can trans- 
fer diabetes into NOD.scid mice in the absence of B cells [57]; (ii) fetal thymic transplants can restore diabetes susceptibility in NOD.scid mice (that is, in the absence of B cells) [58]; and (iii) certain autoreactive $\mathrm{CD}^{+} \mathrm{T}$ cells can efficiently trigger diabetes in B-celldeficient TCR-transgenic animals [15, 59]. Although these experimental systems do not fully repeat the natural history of Type 1 diabetes in wild-type NOD mice, they do make the contribution of B cells to Type 1 diabetes seem more complex than currently thought.

\section{Immunoregulation}

There is evidence suggesting that the autoimmune proclivity of NOD mice results from impaired development and/or function of regulatory T cells. However, other lines of evidence indicate that NOD mice do have functional regulatory cells. Splenocytes from diabetic NOD mice can efficiently transfer diabetes into young immunocompromised NOD mice. Yet when splenocytes from diabetic NOD mice are co-injected with splenocytes from pre-diabetic donors, they lose some of their diabetogenic potential. This suggests that the spleens of pre-diabetic animals contain antidiabetogenic (regulatory) cells [60]. These putative regulatory cells probably develop in the post-natal period, since splenocytes from diabetic mice can transfer disease into neonatal, but not into older NOD hosts. The development of these cells must be thymus-dependent, because thymectomy at three weeks of age accelerates the onset of Type 1 diabetes in female NOD mice [61]. Three $\mathrm{T}$ cell subsets with regulatory properties have been identified in NOD mice: $\mathrm{CD}^{+}{ }^{+} \mathrm{CD} 25^{+}, \mathrm{CD} 4{ }^{+} \mathrm{CD} 62 \mathrm{~L}^{+}$and $\mathrm{NK}$ (natural killer) $\mathrm{T}$ cells $[62,63,64]$. In response to TCR ligation, $\mathrm{CD} 4{ }^{+} \mathrm{CD} 25^{+} \mathrm{T}$ cells do not proliferate (they are anergic), but they can efficiently inhibit the proliferation of naive $\mathrm{T}$ cells in vitro [65]. Both $\mathrm{CD} 4{ }^{+} \mathrm{CD} 25^{+}$and $\mathrm{CD}^{+}{ }^{+} \mathrm{CD} 62 \mathrm{~L}^{+} \mathrm{T}$ cells can delay the onset of diabetes in recipients of diabetogenic $\mathrm{T}$ cells $[62,63,66,67]$. Recent studies suggest that $\mathrm{CD} 4{ }^{+} \mathrm{CD} 25^{+} \mathrm{T}$ cells arise from high-avidity autoreactive $\mathrm{T}$ cells during thymocyte development, i.e. upon engagement of self-peptide/MHC complexes on thymic epithelium [68].

The development of NK T cells in NOD mice is impaired, but not completely abrogated $[64,69,70]$. Natural killer T cells are restricted by CD1d (an MHC class I-like molecule) and usually express an invariant TCR $\alpha$ chain (Vo14-Jo281) [71]. The fact that CD1d-deficient NOD mice develop diabetes earlier and more frequently than wild-type NOD mice $[72,73]$ shows that NOD mice bear functional NK T cells. Similarly, when $\alpha$-galactosyl-ceramide, a glycolipid recognised by NK T cells, was given to NOD mice, this protected them from diabetes $[72,74,75,76]$. Studies in BDC2.5 TCRtransgenic NOD mice provide additional evidence that NK T cells in NOD mice are functional. Massive insu- litis develops at a very young age in BDC2.5-NOD mice $[37,77]$, but their intra-islet $\mathrm{BDC} 2.5 \mathrm{CD}^{+}{ }^{+} \mathrm{T}$ cells do not differentiate into diabetogenic $\mathrm{T}$ cells in the presence of endogenous (non-transgenic) T cells. As a result, these mice have a very low incidence of diabetes [59]. Four lines of evidence suggest that diabetes resistance in BDC2.5-NOD mice is mediated by NK T cells. Firstly, BDC2.5 $\mathrm{CD}^{+} \mathrm{T}$ cells activated in vitro can readily transfer diabetes into NOD.scid recipients, which lack B and T cells [59]. Secondly, the BDC2.5TCR efficiently triggers diabetes in mice deficient in TCR-C $\alpha$ or rag and in mice with NOD.scid backgrounds (all of which lack endogenous $\mathrm{T}$ cells) [77]. Thirdly, the introduction of a CD1d deficiency into these mice abrogates their resistance to diabetes [73]. And finally, splenic DX $5^{+} \mathrm{NK}$ T cells actively suppress the development of diabetes in BDC2.5-NOD.RAG-2-hosts in the presence of $\mathrm{CD}^{+}{ }^{+} \mathrm{T}$ cells from young, prediabetic NOD mice [77].

The mechanisms by which NK T cells inhibit diabetes have been examined in NOD mice expressing a $V \alpha 14-J \alpha 281$ TCR transgene. These mice have increased numbers of NK T cells [78]. It has been found that NK T cells do not inhibit the development of diabetes by blocking the activation of autoreactive $\mathrm{T}$ cells, but possibly by inhibiting the differentiation of antigen-activated $\mathrm{T}$ cells into effectors producing interferon- $\gamma$ (IFN- $\gamma$ ) [79]. The reconstitution of NOD.scid mice with thymic pre-T cells from various strains of mice has shown that defective NK T cell development in NOD mice results from defects intrinsic to $\mathrm{T}$ cells, rather than from defects in thymic stromal cells [80]. Despite these observations, the role played by impaired NK T cell development in the pathogenesis of Type 1 diabetes remains unclear.

\section{Co-stimulation versus autoreactivity and immunoregulation}

Expression of transgenic B7.1 molecules in beta cells of NOD mice accelerates the onset of Type 1 diabetes, indicating that this co-stimulatory molecule, when expressed locally, can amplify the diabetogenic autoimmune response. Subsequent gene-targeting experiments, however, showed that the role of co-stimulatory molecules in Type 1 diabetes is more complex.

Although treatment of young NOD mice with CTLA-4-Ig inhibits the development of diabetes (presumably by blocking co-stimulatory molecules on APCs) [81], NOD mice deficient in CD28, as well as NOD mice deficient in B7.1/B7.2, have a higher incidence and faster onset of diabetes than wild-type NOD mice $[62,82]$. This is because the development of regulatory $\mathrm{CD}^{+}{ }^{+} \mathrm{CD} 25^{+} \mathrm{T}$ cells is controlled, at least in part, by CD28/B7 interactions $[62,82]$. So in the absence of CD28 or B7 molecules, these T cells do not develop properly. 
Interactions between CD40 and CD154 also help maintain the balance between effector and regulatory $\mathrm{T}$ cells in immune responses, albeit through a different mechanism. Whereas CD154 blockade inhibits CD4+ $\mathrm{T}$ cell help (see above), it has no effect on the development or function of regulatory $\mathrm{CD} 4{ }^{+} \mathrm{CD} 25^{+} \mathrm{T}$ cells, at least in NOD mice (Serra et al., submitted). As helper $\mathrm{CD}^{+} \mathrm{T}$ cells oppose the immunosuppressive activity of regulatory $\mathrm{CD} 4{ }^{+} \mathrm{CD} 25^{+} \mathrm{T}$ cells, we proposed that CD154 blockade inhibits diabetogenesis by promoting "unopposed" suppression of diabetogenic T cell responses by these regulatory $\mathrm{T}$ cells. $\mathrm{TNF} / \mathrm{d}$ TNFR [67] and TRANCE/RANK signals [83] have also been implicated in the development of $\mathrm{CD} 4{ }^{+} \mathrm{CD} 25^{+} \mathrm{T}$ cells. Hence, manipulation of these costimulatory pathways could be important for the therapy of Type 1 diabetes.

\section{Cytokines}

Cytokines play important roles in the development, activation, recruitment and function of $\mathrm{T}$ cells and APCs, but can also function as effectors of beta cell death. Although cytokines are typically classed as proinflammatory and anti-inflammatory, their effects on the natural history of Type 1 diabetes are more a function of the location, timing and duration of expression than a function of the subgroup they belong to.

\section{Anti-inflammatory cytokines}

IL-2 is a T cell growth factor. However, IL-2 deficiency causes a multi-organ inflammatory syndrome which results from impaired development of regulatory $\mathrm{CD} 4{ }^{+} \mathrm{CD} 25^{+} \mathrm{T}$ cells [84]. Thus IL-2 can be regarded as an anti-inflammatory cytokine. Expression of a RIP-driven $i l-2$ transgene in beta cells of NOD mice accelerated the development of diabetes, possibly because it promoted the growth of islet-infiltrating $\mathrm{T}$ cells in situ [85]. This transgene also induced diabetes in NOD.scid mice [86], suggesting that it promoted diabetes by impairing beta cell function.

Unlike IL-2, IL-4 is clearly an anti-diabetogenic cytokine [64, 87, 88]. Expression of a RIP-driven il-4 transgene protected NOD mice from insulitis and diabetes by inducing immunoregulatory Th2 cells [89]. Yet when this transgene was expressed in BDC2.5NOD mice, it enhanced the pathogenicity of TCRtransgenic $\mathrm{T}$ cells, suggesting that, produced in situ, IL-4 can potentiate the growth and/or activation of autoreactive Th1 cells [89]. However, it does not seem likely that IL-4 plays a role in the natural history of Type 1 diabetes, as NOD mice deficient in IL-4 have a normal incidence of diabetes with normal kinetics [90, 91]. An alternative explanation is that the absence of IL-4 in these mice is compensated by other cytokines, e.g. IL-13, which can prevent diabetes in NOD mice [92] and shares a common receptor subunit with IL-4 [93]. Studies of NOD mice deficient in IL-4 receptor $\alpha$ chain may clarify this possibility.

Another anti-inflammatory cytokine initially thought to have diabetogenic activity is IL-6. The treatment of NOD mice with an anti-IL-6 antibody inhibited the development of Type 1 diabetes [94], whereas expression of a RIP-il-6 transgene in non-diabetes-prone mice induced islet inflammation [95]. Surprisingly, expression of this transgene in NOD mice delayed the onset of diabetes [96], possibly by inducing Th2 cells [97]. Interleukin-10, another Th2type cytokine, has been shown to have diabetogenic and anti-diabetogenic effects. Systemic treatment of NOD mice with recombinant IL-10 inhibited the development of Type 1 diabetes [99]. However, when this cytokine was expressed locally (in pancreatic islets), it promoted Type 1 diabetes [44, 99, 100]. Despite the above, NOD mice deficient in IL-10 develop diabetes normally, which suggests that IL-10 does not play a role in spontaneous development of the disease, or that its role is compensated by other mechanisms [91]. Expression of TGF- $\beta$, a powerful negative regulator of T-cell-mediated immune responses [101], in NOD islet cells altered APC preference and polarised islet antigen-specific responses towards a Th2 phenotype, inhibiting the development of insulitis and diabetes [102, 103].

\section{Pro-inflammatory cytokines}

Interleukin-12 is a pro-inflammatory cytokine necessary for the development of IFN- $\gamma$-producing Th1 cells. Several observations suggest that IL-12 plays an important role in diabetogenesis. Firstly, the progression of insulitis to overt diabetes in NOD mice is associated with increasing amounts of IL-12 in pancreatic islets [104]. Secondly, genetic susceptibility to human Type 1 diabetes is associated with il-12 p40 gene polymorphism [105]. In addition, the administration of recombinant IL-12 promotes diabetes, and IL-12 blockade inhibits it $[106,107,108,109,110]$, although this depends on when the treatment begins [108, 110]. However, like IL-4- and IL-10-deficient NOD mice, NOD mice deficient in IL-12 have a normal incidence of diabetes with normal kinetics [111], suggesting that the role of IL-12 in the disease process is compensated by other cytokines, e.g. IL-2 [112].

Interferon- $\gamma$ is another Th1-type cytokine with proand anti-diabetogenic activities. Whereas IFN- $\gamma$ blockade protects NOD mice from diabetes [113], NOD mice deficient in IFN- $\gamma$ - and NOD mice deficient in IFN- $\gamma$ receptor beta chain develop diabetes with normal incidence $[92,114,115,116,117]$. Although NOD mice deficient in IFN- $\gamma$ receptor alpha chain do not develop diabetes [117], there is compel- 
ling evidence that resistance to diabetes in these mice is not caused by IFN- $\gamma$ receptor deficiency, but by the presence of a linked anti-diabetogenic 129 allele [115, 116]. Overexpression of a dominant negative IFN- $\gamma$ receptor transgene in islet beta cells made them unresponsive to the effects of IFN- $\gamma$ on beta cells, i.e. upregulation of MHC class I expression, but did not inhibit diabetogenesis [118]. This indicates that IFN- $\gamma$ receptor signalling in beta cells is not an essential component of the disease process. Interferon regulatory factor- 1 , a transcription factor induced by IFN- $\alpha$, IFN- $\beta$ and IFN- $\gamma$, plays a key role in Th1 cell development [119]. Unlike NOD mice deficient in IFN- $\gamma$, NOD mice which are deficient in interferon regulatory factor-1 develop neither diabetes nor insulitis [120], suggesting that lack of IFN- $\gamma$ in IFN- $\gamma$-deficient NOD mice is compensated by IFN- $\alpha$ and/or IFN- $\beta$. The development of diabetes in $R I P$-IFN- $\alpha$-transgenic mice supports this possibility [121].

Another pro-inflammatory cytokine which contributes to the pathogenesis of Type 1 diabetes in NOD mice is TNF $\alpha$. Given to neonatal NOD mice, TNF $\alpha$ exacerbates Type 1 diabetes [122]. However, when given to older animals, it inhibits disease progression [123]. Studies in RIP-TNF $\alpha$-transgenic mice [44, 124] have shown that local production of TNF $\alpha$ promotes diabetogenesis by enhancing APC function and the development of T-helper-independent $\mathrm{CD}^{+}$effector cells. In contrast, prolonged treatment of adult NOD mice with recombinant TNF $\alpha$ attenuates TCR signals [125], induces $T$ cell tolerance [126] and generates regulatory $\mathrm{CD}^{+}{ }^{+} \mathrm{CD} 25^{+} \mathrm{T}$ cells [67]. Studies in NOD mice deficient in TNF receptor- 1 have also documented a role for TNF $\alpha$ as effector molecule in Type 1 diabetes [127, 128].

The pathogenesis of Type 1 diabetes also involves cytokines not discussed here. To the best of our knowledge, these cytokines have not been studied in the context of cytokine-transgenic or gene-targeted NOD mice and were therefore omitted. It is also likely that chemokines play essential, non-redundant roles in the pathogenesis of Type 1 diabetes, but very little is known about the specific nature of these roles. One exception is macrophage inflammatory protein $1 \alpha$ (MIP-1 $\alpha$ ), a member of the CC chemokine family that is expressed by activated islet-specific $\mathrm{CD}^{+}{ }^{+} \mathrm{Th} 1$ cells. NOD mice deficient in MIP- $1 \alpha$ develop a significantly reduced incidence of diabetes [129]. (For detailed reviews on the role of cytokines, chemokines and their receptors in Type 1 diabetes, please see references [130, 131, 132]).

\section{Adhesion molecules}

To study the contribution of intercellular adhesion molecule-1 (ICAM-1) and L-selectin (CD62L) to the pathogenesis of Type 1 diabetes, NOD mice lacking these adhesion molecules have been produced [100, 133, 134]. Expressed on multiple cell types, including beta cells and vascular endothelial cells, ICAM-1 interacts with leucocyte-function-associated antigen-1 (LFA-1) on T cells and delivers a potent co-stimulatory signal which influences the fate of activated $\mathrm{T}$ cells in inflammatory lesions [135]. NOD mice deficient in ICAM-1 do not develop insulitis, even in the presence of a diabetogenic RIP-il-10 transgene [100, 136]. Moreover, short-term treatment of young NOD mice with an anti-ICAM-1 mAb has been shown to inhibit the development of Type 1 diabetes [137]. Nevertheless, splenocytes from mAb-treated NOD mice did not transfer diabetes into NOD.scid recipients, suggesting that ICAM-1 blockade has tolerogenic properties [137]. Interestingly, transient blockade of the ICAM1/LFA-1 interaction in diabetic NOD mice (with recombinant soluble ICAM-1) caused a sustained reversal of diabetes in a large number of animals, raising the possibility that interactions between ICAM-1 and LFA-1 contribute to diabetogenesis through more than one mechanism [137]. The other adhesion molecule for which gene-targeted NOD mice are available is CD62L. Non-obese diabetic mice given an antiCD62L mAb developed neither insulitis nor Type 1 diabetes [138], whereas CD62L-deficient NOD mice developed diabetes normally [134].

\section{Evolution of insulitis to overt diabetes}

Non-obese diabetic mice begin to develop insulitis at about 3 weeks of age, but do not become diabetic until at least nine weeks later. Studies of the fate of NRPA7/V7-reactive $\mathrm{CD}^{+} \mathrm{T}$ cells in wild-type NOD mice using peptide/MHC tetramers showed that progression of insulitis to overt diabetes in NOD mice is associated with "avidity maturation" of this T cell subset [23]. As pre-diabetic NOD mice age, their islet-associated $\mathrm{CD}^{+} \mathrm{T}$ cells contain increasing numbers of NRP-A7reactive cells, and these cells bind $\mathrm{NRP}-\mathrm{A} 7 / \mathrm{K}^{\mathrm{d}}$ tetramers with increasing avidity. Repeated treatment of pre-diabetic NOD mice with soluble NRP-A7 peptide blunted the avidity maturation of the NRP-A7-reactive $\mathrm{CD}^{+} \mathrm{T}$ cell population by deleting clonotypes expressing high-affinity TCRs and expanding clonotypes expressing low-affinity TCRs. This inhibited production of CTLs and halted the progression of insulitis to diabetes. It is likely that avidity maturation is not unique to NRP-A7/V7-reactive T cells, but rather a general phenomenon in autoimmune $\mathrm{T}$ cell responses.

By comparing the fate of TCR-transgenic CD8 ${ }^{+} \mathrm{T}$ cells expressing high- or low-affinity NRP-A7/NRPV7-reactive TCRs in TCR-transgenic NOD mice, we recently showed that central and peripheral tolerance selectively decrease the size of the high-avidity $\mathrm{T}$ cell pool. This study also showed that autoimmune inflammation fuels the expansion of this pool (Han et al., un- 
published observations). The results provide a developmental basis for $\mathrm{T}$ cell avidity maturation in the context of autoimmunity. They also support the idea that beta cell destruction in Type 1 diabetes is executed by a progressively expanding, but initially small population of high-avidity clonotypes that evade peripheral tolerance by localising into inflamed pancreatic islets.

\section{Beta cell destruction}

Several lines of evidence indicate that CD8 ${ }^{+}$CTLs, along with $\mathrm{CD}^{+} \mathrm{T}$ cells, are major effectors of beta cell destruction in Type 1 diabetes. The former are consistently present in islets of NOD mice [10], can transfer diabetes into NOD.scid mice $[139,140]$ and can kill beta cells in vivo of mice resistant to Type 1 diabetes [141]. Studies of NOD mice expressing the 8.3-TCR $\beta$ transgene provided the first evidence that CD8 ${ }^{+}$CTLs contribute to beta cell loss in spontaneous Type 1 diabetes. These mice have a minor (but selective) increase in the frequency of beta-cell-reactive $\mathrm{CD}^{+} \mathrm{T}$ cells and owing to increased recruitment of $\mathrm{CD}^{+}$(but not $\mathrm{CD}^{+}$) $\mathrm{T}$ cells into islets, develop accelerated Type 1 diabetes [14]. On the other hand, there is evidence that beta cell destruction in Type 1 diabetes is also effected by CD4+ ${ }^{+}$cells. Thus beta-cell-autoreactive $\mathrm{CD}^{+}{ }^{+} \mathrm{T}$ cell clones can transfer disease into immunocompromised NOD mice [142], and monoclonal TCR-transgenic NOD mice expressing I-Ag7-restricted TCRs develop accelerated diabetes [15, 59]. However, the results of these studies in TCR $\alpha \beta$-transgenic NOD mice should be interpreted with caution, as the unusually high frequencies of autoreactive $\mathrm{CD}^{+}{ }^{+}$or $\mathrm{CD} 8{ }^{+} \mathrm{T}$ cells in these animals could overwhelm the mechanisms which, in non-transgenic mice, would prevent the relevant $\mathrm{T}$ cells from causing insulitis upon activation.

Various animal models have been developed to test the role of two major pathways of cell-mediated cytotoxicity in Type 1 diabetes, perforin and Fas. Perforindeficient NOD mice develop insulitis but rarely become diabetic, implicating perforin-expressing CTLs as effectors of beta cell destruction in Type 1 diabetes [143]. In contrast, Fas-deficient NOD.Fas ${ }^{l p r}$ mice do not develop diabetes or insulitis [144], and transgenic NOD mice expressing FasL in islet beta cells develop an accelerated form of Type 1 diabetes (owing to beta cell fratricide) [145]. NOD mice which are heterozygous for the FasLgld mutation are also resistant to diabetes [146]. Taken together, these results suggest that the Fas/FasL pathway of cell-mediated cytotoxicity could, by mediating lysis of beta cells by disease-initiating CTLs, be key to the initiation of Type 1 diabetes. In support of this hypothesis, 8.3-CD8 ${ }^{+}$CTLs, which are representative of the earliest $\mathrm{CD} 8+\mathrm{T}$ cells propagated from islets of wild-type NOD mice, kill beta cells exclusively via Fas [147]. However, Fas-deficient islet grafts are readily destroyed in spontaneously diabetic NOD mice [148], indicating that Fas-mediated beta cell cytotoxicity is not an essential mechanism of beta cell destruction at later stages of the disease process, where perforin and soluble effectors such as TNF $\alpha$ possibly play a more important role. Studies with TCR-transgenic mice have shown that different $\mathrm{T}$ cell clones can kill the same targets (beta cells) via different mechanisms. So whereas BDC2.5$\mathrm{CD} 4{ }^{+} \mathrm{T}$ cells kill beta cells through a pathway dependent on TNF receptors [128], 4.1-CD4+ CTLs do so via Fas [149].

\section{Genetics}

MHC-linked genes. MHC class II genes are a major component of genetic susceptibility and resistance to many autoimmune disorders, including Type 1 diabetes. NOD mice deficient in MHC class II expression owing to inactivation of the class II-transactivator do not develop diabetes, implying that MHC class II molecules are essential to the development of diabetes [150]. In humans MHC-linked susceptibility and resistance to Type 1 diabetes are primarily associated with the $H L A-D Q B 1$ locus. Alleles encoding $\mathrm{DQ} \beta$ chains with Ser, Ala or Val at position 57 generate risk, whereas alleles encoding DQ $\beta$ chains with Asp at this position provide different degrees of protection [11]. The NOD mouse is homozygous for a unique $\mathrm{H}-$ 2 haplotype $\left(H-2^{g 7}\right)$. This haplotype carries a nonproductive $I-E \alpha$ gene and encodes an I-A $\alpha^{\mathrm{d} / \mathrm{I}-\mathrm{A} \beta \mathrm{g} 7}$ heterodimer in which the His and Asp found at positions 56 and 57 in most I-A $\beta$ chains are replaced by Pro and Ser respectively. Studies of congenic NOD mice expressing non-NOD MHC haplotypes, and of NOD mice expressing $I-E \alpha^{d}$, I-E $\alpha^{k}$, modified $I-A \beta^{g 7}$, $I-A \alpha^{k} / I-A \beta^{k}$ or $I-A \beta^{d}$ transgenes have proven that class II molecules play a direct role in providing susceptibility or resistance to Type 1 diabetes (reviewed in [11]). As MHC molecules play a pivotal role in $\mathrm{T}$ cell development, some authors have hypothesised that protective MHC molecules provide resistance to Type 1 diabetes by tolerising autoreactive $\mathrm{T}$ cells [151]. Studies in MHC-congenic NOD mice have not found evidence for $\mathrm{T}$ cell tolerance (the mice were resistant to diabetes despite exporting autoreactive $\mathrm{T}$ cells to the periphery). Consequently it was later proposed that MHC-associated resistance to Type 1 diabetes was caused by immunoregulation or immune deviation [13, 152, 153, 154]. This, however, assumes that "tolerance" would target all autoreactive T cells, regardless of pathogenicity, which means the presence of circulating autoreactive $\mathrm{T}$ cells in the animals would be taken to imply absence of deletional tolerance. 
Evidence, at least in mice, for a relationship between deletion of certain highly diabetogenic $\mathrm{CD}^{+} \mathrm{T}$ cells and the MHC-linked resistance to Type 1 diabetes comes from our studies with 4.1-TCR-transgenic NOD mice $[12,155,156]$. Here thymocytes expressing the 4.1-TCR were found to undergo central deletion in $H-2^{g 7 / b}, H-2^{g 7 / k}, H-2^{g 7 / q}$ and $H-2^{g 7 / n b l}$ NOD mice resistant to Type 1 diabetes, a process which happened by engaging anti-diabetogenic MHC class II molecules on bone marrow-derived APCs [12]. Expression in 4.1-NOD mice of anti-diabetogenic MHC class II transgenes such as $I-E \alpha^{k}, I-A^{d}$ and $I-A^{g 7 P D}$ (mutated $\mathrm{I}-\mathrm{A}^{\mathrm{g} 7}$ encoding Pro and Asp at positions 56 and 57) also led to various degrees of 4.1-thymocyte tolerance and resistance to Type 1 diabetes [156]. This ability of anti-diabetogenic MHC class II molecules to tolerise autoreactive $\mathrm{CD}^{+}{ }^{+}$thymocytes is not universal, as neither I-E $\alpha^{k}$ nor I-Ag7PD molecules tolerised $\mathrm{CD} 4{ }^{+}$thymocytes expressing the BDC2.5-TCR [157, 158]. Collectively, these data suggest that in nonTCR-transgenic NOD mice protective MHC class II alleles afford resistance to Type 1 diabetes by tolerising a group of highly pathogenic, MHC-promiscuous, 4.1-like $\mathrm{CD}^{+}{ }^{+} \mathrm{T}$ cells which play a critical role in diabetogenesis. 4.1-CD4 ${ }^{+} \mathrm{T}$ cells would be representative of this $\mathrm{T}$ cell subpopulation. Although speculative, this interpretation is consistent with the observation that the anti-diabetogenic activity of class II molecules in both wild-type and 4.1-TCR-transgenic NOD mice maps to residues around I-A $\beta$ and I-E $\beta$ chain position 57 [156], which are also implicated in the DQB1-linked resistance to Type 1 diabetes in humans and non-TCR-transgenic NOD mice [11]. Whether protective MHC class II molecules also afford resistance to diabetes by selecting regulatory $\mathrm{T}$ cells remains to be determined.

A number of HLAs, including HLA-DR3, HLADR4, HLA-DQ6 and HLA-DQ8, have been expressed in NOD mice to evaluate the role of these molecules in the pathogenesis of Type 1 diabetes $[150,160,161$, 162, 163, 164]. The HLA-DQ8 molecule, which imparts susceptibility to human Type 1 diabetes, can present most of the major islet autoantigens to autoreactive $\mathrm{CD} 4{ }^{+} \mathrm{T}$ cells in NOD mice both in vitro and in vivo $[159,160]$. The fact that $H L A-D Q 8$-transgenic NOD mice which are deficient in $\mathrm{I}-\mathrm{A}^{\mathrm{g} 7}$ do not spontaneously develop Type 1 diabetes [161] does not imply that the HLA-DQ8 molecule is not diabetogenic. Probably resistance to diabetes in these mice results from the introduction into the NOD genetic background of non-NOD genetic elements linked to the IA $\beta$ mutation in the 129 background, which was introduced into transgenic mice to ensure that they do not express murine MHC class II molecules. In general, these studies of HLA-transgenic mice suggest that HLA-DQ8 and HLA-DQ3 do impart susceptibility and that HLA-DR4 and HLA-DQ6 molecules afford resistance to Type 1 diabetes $[161,164,165]$.
Systemic expression of an $H-2 L d$ transgene (a nonNOD MHC class I gene) in NOD mice reduced the severity of insulitis and inhibited the development of diabetes, suggesting that MHC class I genes play a part in resistance to Type 1 diabetes [166]. It has since been shown that the Idd13-linked resistance to diabetes maps to the $\beta 2 \mathrm{~m}$ locus, and that transgenic expression of the non-NOD allele of $\beta 2 m$ in $\beta 2 m$-deficient NOD mice affords resistance to diabetes $[167,168]$. Although the mechanisms by which the $\beta 2 m$ dimorphism affords susceptibility or resistance to diabetes are unclear, these findings strongly support the idea that MHC class I-restricted $\mathrm{T}$ cells are necessary for diabetogenesis to occur. Importantly, a recent study in HLA-transgenic NOD mice has suggested that this is not peculiar to murine MHC class I molecules. When the HLA-A2 allele, which is associated with Type 1 diabetes in humans, was transgenically expressed in NOD mice, it also accelerated the onset of diabetes [169].

Non-MHC-linked genes. Diabetogenesis in NOD mice results from complex interactions between the MHC and multiple (i.e. as many as 20) non-MHC-linked genetic elements (Idd) $[170,171,172,173,174,175$, 176, 177, 178]. The diabetogenic and anti-diabetogenic activities of Idd loci have been studied in congenic NOD mice. In most cases, NOD alleles at Idd loci confer diabetes susceptibility, whereas non-NOD alleles at these loci impart resistance. In other cases, the non-NOD alleles (e.g. at Idd7 and Idd8) confer susceptibility $[170,171]$ or susceptibility and resistance, depending on the strain of origin. Thus the non-obese normal allele at Idd14 is protective, whereas the B6 allele is more diabetogenic than its NOD counterpart $[171,177]$. For Idd6 the $\mathrm{B} 10$ and $\mathrm{C} 3 \mathrm{H}$ alleles are protective, whereas the PWK allele confers susceptibility $[170,178]$.

Studies of sub-congenic lines have shown that chromosomal intervals originally thought to contain single Idd loci, in fact contain several. For example, the original $I d d 5$ and $I d d 9$ intervals are now thought to contain at least three different Idd genes each [179, 180, 181]. Similarly, IddI7 and IddI8 loci were recently found near the $I d d 3$ and $I d d 10$ loci $[177,183]$. Another example of a locus which was missed in initial mapping studies because of its close linkage to a previously identified Idd locus on the same chromosome is Idd16, which is located on mouse chromosome 17, near the MHC (IddI). There is also evidence that at least two MHC-linked genes other than I-A, $I-E, K$ and $D$ contribute to MHC-linked susceptibility or resistance to diabetes [172, 173, 174, 175].

Most of the aetiological mutations responsible for $I d d$-linked susceptibility and/or resistance to diabetes remain a mystery, but there are some exceptions. As noted above, the Idd 13 chromosomal interval contains the dimorphic $\beta 2 m$ gene, which has been linked conclusively to diabetes risk $[167,168]$. A polymorphism 
at $\mathrm{Ctla} 4$ is an excellent candidate for one Idd5 locus [179], and there is considerable evidence suggesting that $I d d 3$ corresponds to $i l-2$ or $i l 21$ [183]. Some Idd loci afford susceptibility or resistance to more than one autoimmune disease. Thus B6 mice congenic for the NOD alleles at Idd3 and Idd5 loci develop Sjogren's syndrome [184, 185, 186], and NOD mice bearing the B6 alleles at the Idd3 locus are resistant to experimental autoimmune encephalomyelitis [187]. A major challenge facing this field will be to determine the mechanisms through which individual Idd elements actually afford diabetes susceptibility or resistance.

\section{Environmental factors}

Although Type 1 diabetes is a genetic disease, disease concordance between monozygotic twins is close to 40 per cent [188], suggesting that environmental factors help trigger the disease process. About 13 viruses have been associated with Type 1 diabetes in humans and animal models [189]. One potential trigger of Type 1 diabetes in humans is enterovirus infections during childhood [190], which can induce inflammatory reactions capable of causing beta cell damage [191]. Another possible factor is molecular mimicry between viral and beta cell antigens. In this case infection of the host by the virus induces cross-reactive immune responses against beta cells [192]. The effects of enterovirus infections on the pathogenesis of Type 1 diabetes have also been explored in NOD mice [193, 194, 195]. Genetic predisposition to Type 1 diabetes was found to play a major role in the ability of viral infection to lead to overt disease. So whereas infection of the diabetes-resistant strain C57BL/10.H2 ${ }^{g 7}$ failed to trigger insulitis, infection of diabetes-prone NOD mice accelerated disease progression [195]. In this model, infection of beta cells by the virus appears to accelerate disease by enhancing the shedding of "sequestered" beta cell autoantigens into the milieu [195]. However, viral infection is not invariably associated with disease exacerbation; other studies have shown that it can also dampen diabetogenic immune responses [196].

\section{Concluding remarks}

Type 1 diabetes results from a chronic, beta-cell-specific, T-cell-dependent autoimmune process that develops in genetically susceptible individuals. The nature of the immune cell types, genetic elements and autoantigens involved in this complex autoimmune response remains a matter of intense investigation. Fine dissection of the mechanisms underlying the development of spontaneous autoimmune diabetes has benefited tremendously from the availability of numerous lines of genetically manipulated NOD mice. Studies of the natural history of diabetes in NOD mice lacking or overexpressing molecules thought to play key roles in the disease process have provided an understanding of the pathogenesis of Type 1 diabetes in detail that was unthinkable a few years ago. One of the main developments has been the creation of transgenic strains of NOD mice expressing TCRs that target disease-relevant autoantigens. These models provide very useful tools with which to probe the effects of multiple genes, gene polymorphisms and certain environmental factors on the developmental biology and pathogenicity of autoreactive $\mathrm{T}$ cells. Nevertheless, it has become clear that a conclusive understanding of the contribution of specific genes to the pathogenesis of Type $1 \mathrm{di}-$ abetes will not be possible without the development of germ-line-competent embryonic stem cells from NOD mice. Studies with gene-targeted NOD mice derived from such lines will put an end to the potentially confounding contribution of linked diabetogenic or antidiabetogenic alleles to study outcome. Nevertheless the animal models already available today offer numerous possibilities for creating combinatorial models of varying complexity.

\section{Sources}

The studies reviewed in this manuscript were selected from periodical reviews of the literature as well as from PubMed seaches (http://www.ncbi.nlm.nih.gov/ entrez/query.fcgi) using the following key words: NOD and transgene, IDDM and cytokine, NOD and co-stimulation, IDDM genetics, IDDM and immune regulation.

Acknowledgements. Y. Yang is a recipient of a Career Development Award from Juvenile Diabetes Research Foundation and was supported by the Diabetes Foothills Association and Julia McFarlane Diabetes Research Centre Funds. P. Santamaria's work was supported by the Canadian Institutes of Health Research, the Canadian Diabetes Association, the Juvenile Diabetes Research Foundation and the Natural Sciences and Engineering Research Council of Canada. P. Santamaria is a Scientist of the Alberta Heritage Foundation for Medical Research. We thank all the members of our laboratories for technical assistance and scientific discussions, as well as V. Crosbie and C. Courts for their excellent editorial and administrative assistance. We apologise to authors whose work could not be cited here due to space limitations.

\section{References}

1. Wong FS, Visintin I, Wen L, Granata J, Flavell R, Janeway CA (1998) The role of lymphocyte subsets in accelerated diabetes in nonobese diabetic-rat insulin promotor-B7-1 (NOD-RIP-B7-1) mice. J Exp Med 187:1985-1993

2. Balasa B, Davies JD, Lee J, Good A, Yeung B, Sarventnick N (1998) IL-10 impacts autoimmune diabetes via a CD8+ $\mathrm{T}$ cell pathway circumventing the requirement for $\mathrm{CD}^{+} \mathrm{T}$ and B lymphocytes. J Immunol 161:4420-4427 
3. Prochazka M, Serreze D, Worthen SM, Leiter EH (1989) Genetic control of diabetogenesis in NOD/Lt mice: development and analysis of congenic stocks. Diabetes 38: 1446-1455

4. Grattan M, Mi QS, Meagher C, Delovitch TL (2002) Congenic mapping of the diabetogenic locus Idd4 to a $5.2-\mathrm{cM}$ region of chromosome 11 in NOD mice: identification of two potential candidate subloci. Diabetes 51:215-223

5. Brodnicki TC, McClive P, Couper S, Morahan G (2000) Localization of Idd11 using NOD congenic mouse strains: elimination of Slc9a1 as a candidate gene. Immunogenetics 51:37-41

6. Christianson SW, Shultz LD, Leiter EH (1993) Adoptive transfer of diabetes into immunodeficient NOD-scid/scid mice. Relative contributions of $\mathrm{CD}^{+}$and $\mathrm{CD}^{+}{ }^{+} \mathrm{T}$-cells from diabetic versus prediabetic NOD.NON-Thy-1a donors. Diabetes 42:44-55

7. Katz J, Benoist C, Mathis D (1993) Major histocompatibility complex class I molecules are required for the development of insulitis in non-obese diabetic mice. Eur J Immunol 23:3358-3360

8. Wicker LS, Leiter EH, Todd JA et al. (1994) Beta 2-microglobulin-deficient NOD mice do not develop insulitis or diabetes. Diabetes 43:500-504

9. Serreze DV, Leiter EH, Christianson GJ, Greiner D, Roopenian D (1994) Major histocompatibility complex class I-deficient NOD-B2mnull mice are diabetes and insulitis resistant. Diabetes 43:505-509

10. Liblau RS, Wong FS, Mars LT, Santamaria P (2002) Autoreactive $\mathrm{CD} 8+\mathrm{T}$ cells in organ-specific autoimmunity: emerging targets for therapeutic intervention. Immunity $17: 1-6$

11. Tisch R, McDevitt H (1996) Insulin-dependent diabetes mellitus. Cell 85:291-297

12. Schmidt D, Verdaguer J, Averill N, Santamaria P (1997) A mechanism for the major histocompatibility complexlinked resistance to autoimmunity. J Exp Med 186: 1059-1075

13. Katz JD, Wang B, Haskins K, Benoist C, Mathis D (1993) Following a diabetogenic $\mathrm{T}$ cell from genesis through pathogenesis. Cell 74:1089-1100

14. Verdaguer J, Yoon JW, Anderson B et al. (1996) Acceleration of spontaneous diabetes in TCR-beta-transgenic nonobese diabetic mice by beta-cell cytotoxic CD8+ T cells expressing identical endogenous TCR-alpha chains. J Immunol 157:4726-4735

15. Verdaguer J, Schmidt D, Amrani A, Anderson B, Averill N, Santamaria P (1997) Spontaneous autoimmune diabetes in monoclonal $\mathrm{T}$ cell nonobese diabetic mice. J Exp Med 186:1663-1676

16. Graser RT, DiLorenzo TP, Wang F et al. (2000) Identification of a CD8 $\mathrm{T}$ cell that can independently mediate autoimmune diabetes development in the complete absence of CD4 T cell helper functions. J Immunol 164:3913-3918

17. Tarbell KV, Lee M, Ranheim E et al. (2002) CD4+ ${ }^{+}$cells from glutamic acid decarboxylase (GAD)65-specific $\mathrm{T}$ cell receptor transgenic mice are not diabetogenic and can delay diabetes transfer. J Exp Med 196:481-492

18. Kanagawa O, Shimizu J, Vaupel BA (2000) Thymic and postthymic regulation of diabetogenic CD8 T cell development in TCR transgenic nonobese diabetic (NOD) mice. J Immunol 164:5466-5473

19. Santamaria P, Utsugi T, Park BJ, Averill N, Kawazu S, Yoon JW (1995) Beta-cell-cytotoxic $\mathrm{CD}^{+} \mathrm{T}$ cells from nonobese diabetic mice use highly homologous $\mathrm{T}$ cell receptor alpha-chain CDR3 sequences. J Immunol 154:24942503
20. DiLorenzo TP, Graser RT, Ono T et al. (1998) Major histocompatibility complex class I-restricted $\mathrm{T}$ cells are required for all but end stages of diabetes development in nonobese diabetic mice and use a prevalent $\mathrm{T}$ cell receptor alpha chain gene rearrangement. Proc Natl Acad Sci USA 95:12538-12542

21. Serra P, Amrani A, Han B, Yamanouchi J, Thiessen SJ, Santamaria P (2002) RAG-dependent peripheral T cell receptor diversification in $\mathrm{CD}^{+} \mathrm{T}$ lymphocytes. Proc Natl Acad Sci USA 99:15566-15571

22. Anderson B, Park BJ, Verdaguer J, Amrani A, Santamaria P (1999) Prevalent CD8(+) T cell response against one peptide/MHC complex in autoimmune diabetes. Proc Natl Acad Sci USA 96:9311-9316

23. Amrani A, Verdaguer J, Serra P, Tafuro S, Tan R, Santamaria P (2000) Progression of autoimmune diabetes driven by avidity maturation of a T-cell population. Nature 406:739742

24. Amrani A, Serra P, Yamanouchi J et al. (2001) Expansion of the antigenic repertoire of a single $\mathrm{T}$ cell receptor upon T cell activation. J Immunol 167:655-666

25. Trudeau JD, Kelly-Smith C, Verchere CB et al. (2003) Prediction of spontaneous autoimmune diabetes in NOD mice by quantification of autoreactive $\mathrm{T}$ cells in peripheral blood. J Clin Invest 111:217-223

26. Lieberman SM, Evans AM, Han B et al. (2003) Identity of the beta cell antigen targeted by a prevalent population of pathogenic CD8+ T cells in autoimmune diabetes. Proc Natl Acad Sci USA 100:8384-8388

27. Wong FS, Karttunen J, Dumont C et al. (1999) Identification of an MHC class I-restricted autoantigen in type 1 diabetes by screening an organ-specific cDNA library. Nat Med 9:1026-1031

28. Amrani A, Serra P, Yamanouchi J et al. (2002) CD154-dependent priming of diabetogenic CD4(+) T cells dissociated from activation of antigen-presenting cells. Immunity 16:719-732

29. Yoon JW, Yoon CS, Lim HW et al. (1999) Control of autoimmune diabetes in NOD mice by GAD expression or suppression in beta cells. Science 284:1183-1187

30. Winer S, Astsaturov I, Gaedigk R et al. (2002) ICA69(null) nonobese diabetic mice develop diabetes, but resist disease acceleration by cyclophosphamide. J Immunol 168:475482

31. Thebault-Baumont K, Dubois-Laforgue D, Krief P et al. (2003) Acceleration of type 1 diabetes mellitus in proinsulin 2-deficient NOD mice. J Clin Invest 111:851-857

32. Geng L, Solimena M, Flavell RA, Sherwin RS, Hayday AC (1998) Widespread expression of an autoantigenGAD65 transgene does not tolerize non-obese diabetic mice and can exacerbate disease. Proc Natl Acad Sci USA 95:10055-10060

33. Song A, Winer S, Tsui H et al. (2003) Deviation of islet autoreactivity to cryptic epitopes protects NOD mice from diabetes. Eur J Immunol 33:546-555

34. French MB, Allison J, Cram DS et al. (1997) Transgenic expression of mouse proinsulin II prevents diabetes in nonobese diabetic mice. Diabetes 46:34-39

35. Judkowski V, Pinilla C, Schroder K, Tucker L, Sarvetnick N, Wilson DB (2001) Identification of MHC class II-restricted peptide ligands, including a glutamic acid decarboxylase 65 sequence, that stimulate diabetogenic $\mathrm{T}$ cells from transgenic BDC2.5 nonobese diabetic mice. J Immunol 166:908-917

36. Gagnerault MC, Luan JJ, Lotton C, Lepault F (2002) Pancreatic lymph nodes are required for priming of beta cell reactive T cells in NOD mice. J Exp Med 196:369-377 
37. Hoglund P, Mintern J, Waltzinger C, Heath W, Benoist C, Mathis D (1999) Initiation of autoimmune diabetes by developmentally regulated presentation of islet cell antigens in the pancreatic lymph nodes. J Exp Med 189:331-339

38. Zhang Y, O'Brien B, Trudeau J, Tan R, Santamaria P, Dutz JP (2002) In situ beta cell death promotes priming of diabetogenic CD8 T lymphocytes. J Immunol 168:14661472

39. Trudeau JD, Dutz JP, Arany E, Hill DJ, Fieldus WE, Finegood DT (2000) Neonatal beta-cell apoptosis: a trigger for autoimmune diabetes? Diabetes 49:1-7

40. Ridge JP, Di Rosa F, Matzinger P (1998) A conditioned dendritic cell can be a temporal bridge between a CD4+ Thelper and a T-killer cell. Nature 393:474-478

41. Bennett SR, Carbone FR, Karamalis F, Flavell RA, Miller JF, Heath WR (1998) Help for cytotoxic T-cell responses is mediated by CD40 signalling. Nature 393:478-480

42. Schoenberger SP, Toes RE, Voort EI van der, Offringa R, Melief CJ (1998) T-cell help for cytotoxic T lymphocytes is mediated by CD40-CD40L interactions. Nature 393: 480-483

43. Balasa B, Krahl T, Patstone G et al. (1997) CD40 ligandCD40 interactions are necessary for the initiation of insulitis and diabetes in nonobese diabetic mice. J Immunol 159: 4620-4627

44. Green EA, Wong FS, Eshima K, Mora C, Flavell RA (2000) Neonatal tumor necrosis factor alpha promotes diabetes in nonobese diabetic mice by CD154-independent antigen presentation to CD8(+) T cells. J Exp Med 191: 225-238

45. Blair PJ, Riley JL, Harlan DM et al. (2000) CD40 ligand (CD154) triggers a short-term CD4(+) T cell activation response that results in secretion of immunomodulatory cytokines and apoptosis. J Exp Med 191:651-660

46. Greeley SA, Katsumata M, Yu L et al. (2002) Elimination of maternally transmitted autoantibodies prevents diabetes in nonobese diabetic mice. Nat Med 8:399-402

47. Serreze DV, Chapman HD, Varnum DS et al. (1996) B lymphocytes are essential for the initiation of T cell-mediated autoimmune diabetes: analysis of a new "speed congenic" stock of NOD.Ig mu null mice. J Exp Med 184: 2049-2053

48. Akashi T, Nagafuchi S, Anzai K et al. (1997) Direct evidence for the contribution of $\mathrm{B}$ cells to the progression of insulitis and the development of diabetes in non-obese diabetic mice. Int Immunol 9:1159-1164

49. Yang M, Charlton B, Gautam AM (1997) Development of insulitis and diabetes in B cell-deficient NOD mice. J Autoimmun 10:257-260

50. Falcone M, Lee J, Patstone G, Yeung B, Sarvetnick N (1998) B lymphocytes are crucial antigen-presenting cells in the pathogenic autoimmune response to GAD65 antigen in nonobese diabetic mice. J Immunol 161:1163-1168

51. Serreze DV, Fleming SA, Chapman HD, Richard SD, Leiter EH, Tisch RM (1998) B lymphocytes are critical antigen-presenting cells for the initiation of $\mathrm{T}$ cell-mediated autoimmune diabetes in nonobese diabetic mice. J Immunol 161:3912-3918

52. Noorchashm H, Lieu YK, Noorchashm N et al. (1999) IAg7-mediated antigen presentation by B lymphocytes is critical in overcoming a checkpoint in $\mathrm{T}$ cell tolerance to islet beta cells of nonobese diabetic mice. J Immunol 163:743-750

53. Noorchashm H, Noorchashm N, Kern J, Rostami SY, Barker CF, Naji A (1997) B-cells are required for the initiation of insulitis and sialitis in nonobese diabetic mice. Diabetes 46:941-946
54. Greeley SA, Moore DJ, Noorchashm H et al. (2001) Impaired activation of islet-reactive CD4 $\mathrm{T}$ cells in pancreatic lymph nodes of $\mathrm{B}$ cell-deficient nonobese diabetic mice. J Immunol 167:4351-4357

55. Hulbert C, Riseili B, Rojas M, Thomas JW (2001) B cell specificity contributes to the outcome of diabetes in nonobese diabetic mice. J Immunol 167:5535-5538

56. Silveira PA, Johnson E, Chapman HD, Bui T, Tisch RM, Serreze DV (2002) The preferential ability of B lymphocytes to act as diabetogenic APC in NOD mice depends on expression of self-antigen-specific immunoglobulin receptors. Eur J Immunol 32:3657-3666

57. Charlton B, Zhang MD, Slattery RM (2001) B lymphocytes not required for progression from insulitis to diabetes in non-obese diabetic mice. Immunol Cell Biol 79:597-601

58. Chiu PP, Serreze DV, Danska JS (2001) Development and function of diabetogenic T-cells in B-cell-deficient nonobese diabetic mice. Diabetes 50:763-770

59. Kurrer MO, Pakala SV, Hanson HL, Katz JD (1997) Beta cell apoptosis in $\mathrm{T}$ cell-mediated autoimmune diabetes. Proc Natl Acad Sci USA 94:213-218

60. Boitard C, Yasunami R, Dardenne M, Bach JF (1989) T cell-mediated inhibition of the transfer of autoimmune diabetes in NOD mice. J Exp Med 169:1669-1680

61. Dardenne M, Lepault F, Bendelac A, Bach JF (1989) Acceleration of the onset of diabetes in NOD mice by thymectomy at weaning. Eur J Immunol 19:889-895

62. Salomon B, Lenschow DJ, Rhee L et al. (2000) B7/CD28 costimulation is essential for the homeostasis of the CD4+CD25+ immunoregulatory $\mathrm{T}$ cells that control autoimmune diabetes. Immunity 12:431-440

63. Lepault F,Gagnerault MC (2000) Characterization of peripheral regulatory $\mathrm{CD} 4+\mathrm{T}$ cells that prevent diabetes onset in nonobese diabetic mice. J Immunol 164:240-247

64. Hammond KJ, Poulton LD, Palmisano LJ, Silveira PA, Godfrey DI, Baxter AG (1998) alpha/beta-T cell receptor (TCR)+CD4-CD8- (NKT) thymocytes prevent insulin-dependent diabetes mellitus in nonobese diabetic (NOD)/Lt mice by the influence of interleukin (IL)-4 and/or IL-10. J Exp Med 187:1047-1056

65. Thornton AM, Shevach EM (1998) CD4+CD25+ immunoregulatory $\mathrm{T}$ cells suppress polyclonal $\mathrm{T}$ cell activation in vitro by inhibiting interleukin 2 production. J Exp Med 188:287-296

66. Szanya V, Ermann J, Taylor C, Holness C, Fathman CG (2002) The subpopulation of CD4+CD25+ splenocytes that delays adoptive transfer of diabetes expresses L-selectin and high levels of CCR7. J Immunol 169:2461-2465

67. Wu AJ, Hua H, Munson SH, McDevitt HO (2002) Tumor necrosis factor-alpha regulation of CD4+C25+ T cell levels in NOD mice. Proc Natl Acad Sci USA 99:12287-12292

68. Jordan MS, Boesteanu A, Reed AJ et al. (2001) Thymic selection of $\mathrm{CD} 4+\mathrm{CD} 25+$ regulatory $\mathrm{T}$ cells induced by an agonist self-peptide. Nat Immunol 2:301-306

69. Gombert JM, Herbelin A, Tancrede-Bohin E, Dy M, Carnaud C, Bach JF (1996) Early quantitative and functional deficiency of NK1+-like thymocytes in the NOD mouse. Eur J Immunol 26:2989-2998

70. Falcone M, Yeung B, Tucker L, Rodriguez E, Sarvetnick N (1999) A defect in interleukin 12-induced activation and interferon gamma secretion of peripheral natural killer $\mathrm{T}$ cells in nonobese diabetic mice suggests new pathogenic mechanisms for insulin-dependent diabetes mellitus. J Exp Med 190:963-972

71. Kawano T, Cui J, Koezuka Y et al. (1997) CD1d-restricted and TCR-mediated activation of valpha14 NKT cells by glycosylceramides. Science 278:1626-1629 
72. Wang B, Geng YB, Wang CR (2001) CD1-restricted NK T cells protect nonobese diabetic mice from developing diabetes. J Exp Med 194:313-320

73. Shi FD, Flodstrom M, Balasa B et al. (2001) Germ line deletion of the CD1 locus exacerbates diabetes in the NOD mouse. Proc Natl Acad Sci USA 98:6777-6782

74. Naumov YN, Bahjat KS, Gausling R et al. (2001) Activation of CD1d-restricted $\mathrm{T}$ cells protects NOD mice from developing diabetes by regulating dendritic cell subsets. Proc Natl Acad Sci USA 98:13838-13843

75. Hong S, Wilson MT, Serizawa I et al. (2001) The natural killer T-cell ligand alpha-galactosylceramide prevents autoimmune diabetes in non-obese diabetic mice. Nat Med 7:1052-1056

76. Sharif S, Arreaza GA, Zucker P et al. (2001) Activation of natural killer $\mathrm{T}$ cells by alpha-galactosylceramide treatment prevents the onset and recurrence of autoimmune Type 1 diabetes. Nat Med 7:1057-1062

77. Gonzalez A, Andre-Schmutz I, Carnaud C, Mathis D, Benoist C (2001) Damage control, rather than unresponsiveness, effected by protective DX5+ T cells in autoimmune diabetes. Nat Immunol 2:1117-1125

78. Laloux V, Beaudoin L, Jeske D, Carnaud C, Lehuen A (2001) NK T cell-induced protection against diabetes in $\mathrm{V}$ alpha 14$\mathrm{J}$ alpha 281 transgenic nonobese diabetic mice is associated with a Th2 shift circumscribed regionally to the islets and functionally to islet autoantigen. J Immunol 166:3749-3756

79. Beaudoin L, Laloux V, Novak J, Lucas B, Lehuen A (2002) NKT cells inhibit the onset of diabetes by impairing the development of pathogenic $\mathrm{T}$ cells specific for pancreatic beta cells. Immunity 17:725-736

80. Yang Y, Bao M, Yoon JW (2001) Intrinsic defects in the TCell lineage results in natural killer T-cell deficiency and the development of diabetes in the nonobese diabetic mouse. Diabetes 50:2691-2699

81. Lenschow DJ, Ho SC, Sattar H et al. (1995) Differential effects of anti-B7-1 and anti-B7-2 monoclonal antibody treatment on the development of diabetes in the nonobese diabetic mouse. J Exp Med 181:1145-1155

82. Lenschow DJ, Herold KC, Rhee L et al. (1996) CD28/B7 regulation of Th1 and Th2 subsets in the development of autoimmune diabetes. Immunity 5:285-293

83. Green EA, Choi Y, Flavell RA (2002) Pancreatic lymph node-derived CD4(+)CD25(+) Treg cells: highly potent regulators of diabetes that require TRANCE-RANK signals. Immunity 16:183-191

84. Malek TR, Yu A, Vincek V, Scibelli P, Kong L (2002) CD4 regulatory $\mathrm{T}$ cells prevent lethal autoimmunity in IL-2Rbeta-deficient mice. Implications for the nonredundant function of IL-2. Immunity 17:167-178

85. Allison J, McClive P, Oxbrow L, Baxter A, Morahan G, Miller JF (1994) Genetic requirements for acceleration of diabetes in non-obese diabetic mice expressing interleukin2 in islet beta-cells. Eur J Immunol 24:2535-2541

86. Allison J, Oxbrow L, Miller J (1994) Consequences of in situ production of IL-2 for islet cell death. Int Immunol 6:541-549

87. Rapoport MJ, Jaramillo A, Zipris D et al. (1993) Interleukin 4 reverses $\mathrm{T}$ cell proliferative unresponsiveness and prevents the onset of diabetes in nonobese diabetic mice. J Exp Med 178:87-99

88. Mueller R, Krahl T, Sarvetnick N (1996) Pancreatic expression of interleukin-4 abrogates insulitis and autoimmune diabetes in nonobese diabetic (NOD) mice. J Exp Med 184:1093-1099

89. Mueller R, Bradley LM, Krahl T, Sarvetnick N (1997) Mechanism underlying counterregulation of autoimmune diabetes by IL-4. Immunity 7:411-418
90. Wang B, Gonzalez A, Hoglund P, Katz JD, Benoist C, Mathis D (1998) Interleukin-4 deficiency does not exacerbate disease in NOD mice. Diabetes 47:1207-1211

91. Serreze DV, Chapman HD, Post CM, Johnson EA, Suarez-Pinzon WL, Rabinovitch A (2001) Th1 to Th2 cytokine shifts in nonobese diabetic mice: sometimes an outcome, rather than the cause, of diabetes resistance elicited by immunostimulation. J Immunol 166:1352-1359

92. Zaccone P, Phillips J, Conget I et al. (1999) Interleukin-13 prevents autoimmune diabetes in NOD mice. Diabetes 48:1522-1528

93. Kaplan MH, Schindler U, Smiley ST, Grusby MJ (1996) Stat6 is required for mediating responses to IL-4 and for development of Th2 cells. Immunity 4:313-319

94. Campbell IL, Kay TW, Oxbrow L, Harrison LC (1991) Essential role for interferon-gamma and interleukin-6 in autoimmune insulin-dependent diabetes in NOD/Wehi mice. J Clin Invest 87:739-742

95. Campbell IL, Hobbs MV, Dockter J, Oldstone MB, Allison J (1994) Islet inflammation and hyperplasia induced by the pancreatic islet-specific overexpression of interleukin-6 in transgenic mice. Am J Pathol 145:157166

96. DiCosmo BF, Picarella D, Flavell RA (1994) Local production of human IL-6 promotes insulitis but retards the onset of insulin-dependent diabetes mellitus in non-obese diabetic mice. Int Immunol 6:1829-1837

97. Rincon M, Anguita J, Nakamura T, Fikrig E, Flavell RA (1997) Interleukin (IL)-6 directs the differentiation of IL4-producing CD4+ T cells. J Exp Med 185:461-469

98. Pennline KJ, Roque-Gaffney E, Monahan M (1994) Recombinant human IL-10 prevents the onset of diabetes in the nonobese diabetic mouse. Clin Immunol Immunopathol 71:169-175

99. Balasa B, Gunst K van, Jung N et al. (2000) Islet-specific expression of IL-10 promotes diabetes in nonobese diabetic mice independent of Fas, perforin, TNF receptor-1, and TNF receptor-2 molecules. J Immunol 165:28412849

100. Balasa B, La Cava A, Gunst K van et al. (2000) A mechanism for IL-10-mediated diabetes in the nonobese diabetic (NOD) mouse: ICAM-1 deficiency blocks accelerated diabetes. J Immunol 165:7330-7337

101. Gorelik L, Flavell RA (2000) Abrogation of TGFbeta signaling in $\mathrm{T}$ cells leads to spontaneous $\mathrm{T}$ cell differentiation and autoimmune disease. Immunity 12:171-181

102. King C, Davies J, Mueller R et al. (1998) TGF-beta1 alters APC preference, polarizing islet antigen responses towards a Th2 phenotype. Immunity 8:601-613

103. Moritani M, Yoshimoto K, Wong SF et al. (1998) Abrogation of autoimmune diabetes in nonobese diabetic mice and protection against effector lymphocytes by transgenic paracrine TGF-beta1. J Clin Invest 102:499-506

104. Rabinovitch A, Suarez-Pinzon WL, Sorensen O (1996) Interleukin 12 mRNA expression in islets correlates with beta-cell destruction in NOD mice. J Autoimmun 9:645-651

105. Morahan G, Huang D, Ymer SI et al. (2001) Linkage disequilibrium of a type 1 diabetes susceptibility locus with a regulatory IL12B allele. Nat Genet 27:218-221

106. Trembleau S, Penna G, Bosi E, Mortara A, Gately MK, Adorini L (1995) Interleukin 12 administration induces T helper type 1 cells and accelerates autoimmune diabetes in NOD mice. J Exp Med 181:817-821

107. Trembleau S, Penna G, Gregori S, Gately MK, Adorini L (1997) Deviation of pancreas-infiltrating cells to Th2 by interleukin-12 antagonist administration inhibits autoimmune diabetes. Eur J Immunol 27:2330-2339 
108. Fujihira K, Nagata M, Moriyama H et al. (2000) Suppression and acceleration of autoimmune diabetes by neutralization of endogenous interleukin-12 in NOD mice. Diabetes 49:1998-2006

109. Adorini L (2001) Interleukin 12 and autoimmune diabetes. Nat Genet 27:131-132

110. O’Hara RM Jr, Henderson SL, Nagelin A (1996) Prevention of a Th1 disease by a Th1 cytokine: IL-12 and diabetes in NOD mice. Ann NY Acad Sci 795:241-249

111. Trembleau S, Penna G, Gregori S et al. (1999) Pancreasinfiltrating Th1 cells and diabetes develop in IL-12-deficient nonobese diabetic mice. J Immunol 163:2960-2968

112. Zhou W, Zhang F, Aune TM (2003) Either IL-2 or IL-12 is sufficient to direct Th1 differentiation by nonobese diabetic T cells. J Immunol 170:735-740

113. Nicoletti F, Zaccone P, Di Marco R et al. (1996) The effects of a nonimmunogenic form of murine soluble interferon-gamma receptor on the development of autoimmune diabetes in the NOD mouse. Endocrinology 137:55675575

114. Hultgren B, Huang X, Dybdal N, Stewart TA (1996) Genetic absence of gamma-interferon delays but does not prevent diabetes in NOD mice. Diabetes 45:812-817

115. Kanagawa O, Xu G, Tevaarwerk A, Vaupel BA (2000) Protection of nonobese diabetic mice from diabetes by gene(s) closely linked to IFN-gamma receptor loci. J Immunol 164:3919-3923

116. Serreze DV, Post CM, Chapman HD, Johnson EA, Lu B, Rothman PB (2000) Interferon-gamma receptor signaling is dispensable in the development of autoimmune type 1 diabetes in NOD mice. Diabetes 49:2007-2011

117. Wang B, Andre I, Gonzalez A et al. (1997) Interferon-y impacts at multiple points during the progression of autoimmune diabetes. Proc Natl Acad Sci USA 94:1384413849

118. Thomas HE, Parker JL, Schreiber RD, Kay TW (1998) INF-gamma action on panreatic beta cells causes class I MHC upregulation but not diabetes. J Clin Invest 102: 1249-1257

119. Taki S, Sato T, Ogasawara K et al. (1997) Multistage regulation of Th1-type immune responses by the transcription factor IRF-1. Immunity 6:673-679

120. Nakazawa T, Satoh J, Takahashi K et al. (2001) Complete suppression of insulitis and diabetes in NOD mice lacking interferon regulatory factor-1. J Autoimmun 17:119-125

121. Stewart TA, Hultgren B, Huang X, Pitts-Meek S, Hully J, MacLachlan NJ (1993) Induction of type I diabetes by interferon-alpha in transgenic mice. Science 260:1942-1946

122. Yang XD, Tisch R, Singer SM et al. (1994) Effect of tumor necrosis factor alpha on insulin-dependent diabetes mellitus in NOD mice. I. The early development of autoimmunity and the diabetogenic process. J Exp Med 180: 995-1004

123. Jacob CO, Aiso S, Michie SA, McDevitt HO, Acha-Orbea $\mathrm{H}$ (1990) Prevention of diabetes in nonobese diabetic mice by tumor necrosis factor (TNF): similarities between TNF-alpha and interleukin-1. Proc Natl Acad Sci USA 87:968-972

124. Green EA, Eynon EE, Flavell RA (1998) Local expression of TNFalpha in neonatal NOD mice promotes diabetes by enhancing presentation of islet antigens. Immunity 9:733-743

125. Cope AP, Liblau RS, Yang XD et al. (1997) Chronic tumor necrosis factor alters $\mathrm{T}$ cell responses by attenuating T cell receptor signaling. J Exp Med 185:1573-1584

126. McSorley SJ, Soldera S, Malherbe L et al. (1997) Immunological tolerance to a pancreatic antigen as a result of local expression of TNFalpha by islet beta cells. Immunity 7:401-409

127. Kagi D, Ho A, Odermatt B, Zakarian A, Ohashi PS, Mak TW (1999) TNF receptor 1-dependent beta cell toxicity as an effector pathway in autoimmune diabetes. J Immunol 162:4598-4605

128. Pakala SV, Chivetta M, Kelly CB, Katz JD (1999) In autoimmune diabetes the transition from benign to pernicious insulitis requires an islet cell response to tumor necrosis factor alpha. J Exp Med 189:1053-1062

129. Cameron MJ, Arreaza GA, Grattan M et al. (2000) Differential expression of CC chemokines and the CCR5 receptor in the pancreas is associated with progression to type I diabetes. J Immunol 165:1102-1110

130. Kay TW, Darwiche R, Irawaty W, Chong MM, Pennington HL, Thomas HE (2003) The role of cytokines as effectors of tissue destruction in autoimmunity. Adv Exp Med Biol 520:73-86

131. Meagher C, Sharif S, Hussain S, Cameron MJ, Arreaza GA, Delovitch TL (2003) Cytokines and chemokines in the pathogenesis of murine type 1 diabetes. Adv Exp Med Biol 520:133-158

132. Rabinovitch A (2003) Immunoregulation by cytokines in autoimmune diabetes. Adv Exp Med Biol 520:159-193

133. Martin S, Engel NK van den, Vinke A, Heidenthal E, Schulte B, Kolb H (2001) Dominant role of intercellular adhesion molecule- 1 in the pathogenesis of autoimmune diabetes in non-obese diabetic mice. J Autoimmun 17: 109-117

134. Friedline RH, Wong CP, Steeber DA, Tedder TF, Tisch R (2002) L-selectin is not required for T cell-mediated autoimmune diabetes. J Immunol 168:2659-2666

135. Camacho SA, Heath WR, Carbone FR et al. (2001) A key role for ICAM-1 in generating effector cells mediating inflammatory responses. Nat Immunol 2:523-529

136. Moriyama H, Yokono K, Amano K et al. (1996) Induction of tolerance in murine autoimmune diabetes by transient blockade of leukocyte function-associated antigen-1/intercellular adhesion molecule-1 pathway. J Immunol 157: 3737-3743

137. Bertry-Coussot L, Lucas B, Danel C et al. (2002) Longterm reversal of established autoimmunity upon transient blockade of the LFA-1/intercellular adhesion molecule-1 pathway. J Immunol 168:3641-3648

138. Lepault F, Gagnerault MC, Faveeuw C, Bazin H, Boitard C (1995) Lack of L-selectin expression by cells transferring diabetes in NOD mice: insights into the mechanisms involved in diabetes prevention by Mel-14 antibody treatment. Eur J Immunol 25:1502-1507

139. Wong FS, Visintin I, Wen L, Flavell RA, Janeway CA Jr (1996) CD8 T cell clones from young nonobese diabetic NOD islets can transfer rapid onset of diabetes in NOD mice in the absence of CD4 T cells. J Exp Med 183:67-76

140. Nagata M, Santamaria P, Kawamura T, Utsugi T, Yoon JW (1994) Evidence for the role of CD8+ cytotoxic T cells in the destruction of pancreatic beta-cells in nonobese diabetic mice. J Immunol 152:2042-2050

141. Utsugi T, Yoon JW, Park BJ et al. (1996) Major histocompatibility complex class I-restricted infiltration and destruction of pancreatic islets by NOD mouse-derived betacell cytotoxic CD8+ T-cell clones in vivo. Diabetes 45:1121-1131

142. Peterson JD, Haskins K (1996) Transfer of diabetes in the NOD-scid mouse by CD4 T-cell clones. Differential requirement for CD8 T-cells. Diabetes 45:328-336

143. Kagi D, Odermatt B, Seiler P, Zinkernagel RM, Mak TW, Hengartner H (1997) Reduced incidence and delayed on- 
set of diabetes in perforin-deficient nonobese diabetic mice. J Exp Med 186:989-997

144. Itoh N, Imagawa A, Hanafusa T et al. (1997) Requirement of Fas for the development of autoimmune diabetes in nonobese diabetic mice. J Exp Med 186:613-618

145. Chervonsky AV, Wang Y, Wong FS et al. (1997) The role of Fas in autoimmune diabetes. Cell 89:17-24

146. Su X, Hu Q, Kristan JM et al. (2000) Significant role for Fas in the pathogenesis of autoimmune diabetes. J Immunol 164:2523-2532

147. Amrani A, Verdaguer J, Anderson B, Utsugi T, Bou S, Santamaria P (1999) Perforin-independent beta-cell destruction by diabetogenic CD8(+) T lymphocytes in transgenic nonobese diabetic mice. J Clin Invest 103:12011209

148. Allison J, Strasser A (1998) Mechanisms of beta cell death in diabetes: a minor role for CD95. Proc Natl Acad Sci USA 95:13818-13822

149. Amrani A, Verdaguer J, Thiessen S, Bou S, Santamaria P (2000) IL-1alpha, IL-1beta, and IFN-gamma mark beta cells for Fas-dependent destruction by diabetogenic CD4(+) T lymphocytes. J Clin Invest 105:459-468

150. Mora C, Wong FS, Chang CH, Flavell RA (1999) Pancreatic infiltration but not diabetes occurs in the relative absence of MHC class II-restricted CD4 T cells: studies using NOD/CIITA-deficient mice. J Immunol 162:45764588

151. Reich EP, Sherwin RS, Kanagawa O, Janeway CA Jr (1989) An explanation for the protective effect of the MHC class II I-E molecule in murine diabetes. Nature 341:326-328

152. Bohme J, Schuhbaur B, Kanagawa O, Benoist C, Mathis D (1990) MHC-linked protection from diabetes dissociated from clonal deletion of T cells. Science 249:293295

153. Singer SM, Tisch R, Yang XD, McDevitt HO (1993) An Abd transgene prevents diabetes in nonobese diabetic mice by inducing regulatory T cells. Proc Natl Acad Sci USA 90:9566-9570

154. Parish NM, Chandler P, Quartey-Papafio R, Simpson E, Cooke A (1993) The effect of bone marrow and thymus chimerism between non-obese diabetic (NOD) and NODE transgenic mice, on the expression and prevention of diabetes. Eur J Immunol 23:2667-2675

155. Schmidt D, Amrani A, Verdaguer J, Bou S, Santamaria P (1999) Autoantigen-independent deletion of diabetogenic CD4+ thymocytes by protective MHC class II molecules. J Immunol 162:4627-4636

156. Thiessen S, Serra P, Amrani A, Verdaguer J, Santamaria P (2002) T-cell tolerance by dendritic cells and macrophages as a mechanism for the major histocompatibility complex-linked resistance to autoimmune diabetes. Diabetes 51:325-338

157. Kanagawa O, Vaupel BA, Xu G, Unanue ER, Katz JD (1998) Thymic positive selection and peripheral activation of islet antigen- specific T cells: separation of two diabetogenic steps by an I-A(g7) class II MHC beta-chain mutant. J Immunol 161:4489-4492

158. Luhder F, Katz J, Benoist C, Mathis D (1998) Major histocompatibility complex class II molecules can protect from diabetes by positively selecting $\mathrm{T}$ cells with additional specificities. J Exp Med 187:379-387

159. Liu J, Purdy LE, Rabinovitch S, Jevnikar AM, Elliott JF (1999) Major DQ8-restricted T-cell epitopes for human GAD65 mapped using human CD4, DQA1*0301, DQB1*0302 transgenic IA(null) NOD mice. Diabetes 48:469-477
160. Wen L, Wong FS, Sherwin R, Mora C (2002) Human DQ8 can substitute for murine I-Ag7 in the selection of diabetogenic $\mathrm{T}$ cells restricted to $\mathrm{I}-\mathrm{Ag} 7$. J Immunol 168:3635-3640

161. Kudva YC, Rajagopalan G, Raju R et al. (2002) Modulation of insulitis and type 1 diabetes by transgenic HLADR3 and DQ8 in NOD mice lacking endogenous MHC class II. Hum Immunol 63:987-999

162. Moriyama H, Wen L, Abiru N et al. (2002) Induction and acceleration of insulitis/diabetes in mice with a viral mimic (polyinosinic-polycytidylic acid) and an insulin selfpeptide. Proc Natl Acad Sci USA 99:5539-5544

163. Rajagopalan G, Kudva YC, Flavell RA, David CS (2003) Accelerated diabetes in rat insulin promoter-tumor necrosis factor-alpha transgenic nonobese diabetic mice lacking major histocompatibility class II molecules. Diabetes 52:342-347

164. Raju R, Munn SR, David CS (1997) T cell recognition of human pre-proinsulin peptides depends on the polymorphism at HLA DQ locus: a study using HLA DQ8 and DQ6 transgenic mice. Hum Immunol 58:21-29

165. Wen L, Chen NY, Tang J, Sherwin R, Wong FS (2001) The regulatory role of DR4 in a spontaneous diabetes DQ8 transgenic model. J Clin Invest 107:871-880

166. Miyazaki T, Matsuda Y, Toyonaga T, Miyazaki J, Yazaki Y, Yamamura K (1992) Prevention of autoimmune insulitis in nonobese diabetic mice by expression of major histocompatibility complex class I Ld molecules. Proc Natl Acad Sci USA 89:9519-9523

167. Serreze DV, Bridgett M, Chapman HD, Chen E, Richard SD, Leiter EH (1998) Subcongenic analysis of the Idd13 locus in NOD/Lt mice: evidence for several susceptibility genes including a possible role for beta 2 -microglobulin. J Immunol 160:1472-1478

168. Hamilton-Williams EE, Serreze DV, Charlton B et al. (2001) Transgenic rescue implicates beta2-microglobulin as a diabetes susceptibility gene in nonobese diabetic (NOD) mice. Proc Natl Acad Sci USA 98:11533-11538

169. Marron MP, Graser RT, Chapman HD, Serreze DV (2002) Functional evidence for the mediation of diabetogenic $\mathrm{T}$ cell responses by HLA-A2.1 MHC class I molecules through transgenic expression in NOD mice. Proc Natl Acad Sci USA 99:13753-13758

170. Wicker LS, Todd JA, Peterson LB (1995) Genetic control of autoimmune diabetes in the NOD mouse. Annu Rev Immunol 13:179-200

171. McAleer MA, Reifsnyder P, Palmer SM et al. (1995) Crosses of NOD mice with the related NON strain. A polygenic model for IDDM. Diabetes 44:1186-1195

172. Ikegami H, Makino S, Yamato E et al. (1995) Identification of a new susceptibility locus for insulin-dependent diabetes mellitus by ancestral haplotype congenic mapping. J Clin Invest 96:1936-1942

173. Hattori M, Yamato E, Itoh N et al. (1999) Cutting edge: homologous recombination of the MHC class I K region defines new MHC-linked diabetogenic susceptibility gene(s) in nonobese diabetic mice. J Immunol 163:1721-1724

174. Boulard O, Damotte D, Deruytter N, Fluteau G, Carnaud C, Garchon HJ (2002) An interval tightly linked to but distinct from the $\mathrm{H} 2$ complex controls both overt diabetes (Idd16) and chronic experimental autoimmune thyroiditis (Ceat1) in nonobese diabetic mice. Diabetes 51:21412147

175. Mathews CE, Graser RT, Serreze DV, Leiter EH (2000) Reevaluation of the major histocompatibility complex genes of the NOD-progenitor CTS/Shi strain. Diabetes 49:131-134 
176. Lyons PA, Armitage N, Lord CJ et al. (2001) Mapping by genetic interaction: high-resolution congenic mapping of the type 1 diabetes loci Idd10 and Idd18 in the NOD mouse. Diabetes 50:2633-2637

177. Brodnicki TC, Quirk F, Morahan G (2003) A susceptibility allele from a non-diabetes-prone mouse strain accelerates diabetes in NOD congenic mice. Diabetes 52:218-222

178. Rogner UC, Boitard C, Morin J, Melanitou E, Avner P (2001) Three loci on mouse chromosome 6 influence onset and final incidence of type I diabetes in NOD.C3H congenic strains. Genomics 74:163-171

179. Hill NJ, Lyons PA, Armitage N, Todd JA, Wicker LS, Peterson LB (2000) NOD Idd5 locus controls insulitis and diabetes and overlaps the orthologous CTLA4/IDDM 12 and NRAMP1 loci in humans. Diabetes 49:1744-1747

180. Lamhamedi-Cherradi SE, Boulard O, Gonzalez C et al. (2001) Further mapping of the Idd5.1 locus for autoimmune diabetes in NOD mice. Diabetes 50:2874-2878

181. Lyons PA, Hancock WW, Denny P et al. (2000) The NOD Idd9 genetic interval influences the pathogenicity of insulitis and contains molecular variants of $\mathrm{Cd} 30$, Tnfr2, and Cd137. Immunity 13:107-115

182. Podolin PL, Denny P, Armitage N et al. (1998) Localization of two insulin-dependent diabetes (Idd) genes to the Idd10 region on mouse chromosome 3. Mamm Genome 9:283-286

183. Denny P, Lord CJ, Hill NJ et al. (1997) Mapping of the IDDM locus Idd 3 to a $0.35-\mathrm{cM}$ interval containing the interleukin-2 gene. Diabetes 46:695-700

184. Cha S, Nagashima H, Brown VB, Peck AB, HumphreysBeher MG (2002) Two NOD Idd-associated intervals contribute synergistically to the development of autoimmune exocrinopathy (Sjogren's syndrome) on a healthy murine background. Arthritis Rheum 46:1390-1398

185. Boulard O, Fluteau G, Eloy L, Damotte D, Bedossa P, Garchon HJ (2002) Genetic analysis of autoimmune sialadenitis in nonobese diabetic mice: a major susceptibility region on chromosome 1. J Immunol 168:4192-4201

186. Brayer J, Lowry J, Cha S et al. (2000) Alleles from chromosomes 1 and 3 of NOD mice combine to influence
Sjogren's syndrome-like autoimmune exocrinopathy. J Rheumatol 27:1896-1904

187. Encinas JA, Wicker LS, Peterson LB et al. (1999) QTL influencing autoimmune diabetes and encephalomyelitis map to a $0.15-\mathrm{cM}$ region containing I12. Nat Genet 21:158-160

188. Hawa MI, Beyan H, Buckley LR, Leslie RD (2002) Impact of genetic and non-genetic factors in type 1 diabetes. Am J Med Genet 115:8-17

189. Jun HS, Yoon JW (2001) The role of viruses in type I diabetes: two distinct cellular and molecular pathogenic mechanisms of virus-induced diabetes in animals. Diabetologia 44:271-285

190. Hyoty H, Taylor KW (2002) The role of viruses in human diabetes. Diabetologia 45:1353-1361

191. See DM, Tilles JG (1995) Pathogenesis of virus-induced diabetes in mice. J Infect Dis 171:1131-1138

192. Kaufman DL, Erlander MG, Clare-Salzler M, Atkinson MA, Maclaren NK, Tobin AJ (1992) Autoimmunity to two forms of glutamate decarboxylase in insulin-dependent diabetes mellitus. J Clin Invest 89:283-292

193. Serreze DV, Ottendorfer EW, Ellis TM, Gauntt CJ, Atkinson MA (2000) Acceleration of type 1 diabetes by a coxsackievirus infection requires a preexisting critical mass of autoreactive T-cells in pancreatic islets. Diabetes 49: 708-711

194. Horwitz MS, Bradley LM, Harbertson J, Krahl T, Lee J, Sarvetnick N (1998) Diabetes induced by Coxsackie virus: initiation by bystander damage and not molecular mimicry. Nat Med 4:781-785

195. Davydova B, Harkonen T, Kaialainen S, Hovi T, Vaarala O, Roivainen M (2003) Coxsackievirus immunization delays onset of diabetes in non-obese diabetic mice. J Med Virol 69:510-520

196. Tracy S, Drescher KM, Chapman NM et al. (2002) Toward testing the hypothesis that group B coxsackieviruses (CVB) trigger insulin-dependent diabetes: inoculating nonobese diabetic mice with CVB markedly lowers diabetes incidence. J Virol 76:12097-12111 